\title{
JUDICIAL ABDICATION OF MILITARY TORT ACCOUNTABILITY: BUT WHO IS TO GUARD THE GUARDS THEMSELVES? $\dagger$
}

\author{
BARRY KELLMAN*
}

\section{INTRODUCTION}

In this era of thermonuclear weapons, America must uphold its historical commitment to be a nation of law. Our strength grows from the resolve to subject military force to constitutional authority. Especially im these times when weapons proliferation can lead to nuclear winter, when weapons production can cause cancer, when soldiers die unnecessarily im the name of readiness: those who control military force must be held accountable under law. As the Supreme Court recognized a generation ago,

the Founders envisioned the army as a necessary institution, but one dangerous to liberty if not confined within its essential bounds. Their fears were rooted in history. They knew that ancient republics had been overthrown by their military leaders.

…

... We cannot close our eyes to the fact that today the peoples of many nations are ruled by the military.

We should not break faith with this Nation's tradition of keeping military power subservient to civilian authority, a tradition which we believe is firmly embodied in the Constitution. ${ }^{1}$

Our fears may be rooted in more recent history. During the decade of history's largest peacetime military expansion (1979-1989), more than 17,000 service persolmel were killed in training accidents. ${ }^{2}$ In the same period, virtually every facility in the nuclear bomb complex has been re347.

$\dagger$ “[S]ed Quis custodiet ipsos custodes?" Decimus Junius Juvenal (A.D. 50-130). SATIRES VI

* Professor, DePaul University College of Law; J.D. Yale, 1976. The author would like to recognize the contribution of Professor James Wilson of Cleveland State University College of Law in overcoming critical hurdles in the preparation of this essay. Renaining lapses and neglected details are wholly the author's responsibility.

1. Reid v. Covert, 354 U.S. 1, 23-24, 40 (1956) (footnote omitted) (soldiers' wives, accused of inurder, may not be denied trial by jury in court of law and forced to stand trial before courtmartial).

2. Mundy, States News Service, Nov. 16, 1989 (newswire report concerning aceidental military deaths during peacctine). 
vealed to be contaminated with radioactive and poisonous materials; the clean-up costs are projected to exceed $\$ 100$ billion. ${ }^{3}$ Headlimes of fatal B1B bomber crashes, ${ }^{4}$ the downing of an Iranian passenger plane, ${ }^{5}$ the Navy's frequent accidents ${ }^{6}$ includimg the fatal crash of a fighter plane into a Georgia apartment complex, ${ }^{7}$ remind Americans that a tragic price is paid to support the military establishment. Other coinmentaries may distinguish between the specific losses that might have been preventable and those which were the random consequence of what is undeniably a dangerous military program. This Article can only repeat the questions of the parents of those who have died: "Is the military accountable to anyone? Why is it allowed to keep making the same mistakes? How many more hives must be lost to senseless accidents?"8

This Article describes a judicial concession of the law's domain, ironically impelled by concerns for "national security." In three recent controversies mvolving weapons testing, the judiciary has disallowed tort accountability for serious and unwarranted imjuries. In United States $v$. Stanley, ${ }^{9}$ the Supreme Court ruled that an Army sergeant, unknowingly drugged with LSD by the Central Intelligence Agency, could not pursue a claim for deprivation of his constitutional rights. In Allen $v$. United States, ${ }^{10}$ civilian victims of atmospheric atomic testing were denied a right of tort recovery against the government officials who inanaged and performed the tests. Finally, in Boyle v. United Technologies, ${ }^{11}$ the Supreme Court ruled that private weapons manufacturers enjoy immumity froin product liability actions alleging design defects. A critical analysis of these decisions reveals that the judiciary, notably the Rehnquist Court, has abdicated its responsibility to review civil matters involving the military security establishment. ${ }^{12}$

3. Wald, Scientists, Citing Peril, Ask Delay in New Plants for Bomb Material, N.Y. Times, Dec. 21,1989 , at 16 , col. 5 .

4. North, Military Air Accident Rates Parallel 1986's Low Levels, Aviation WEEK AND SPACE TeCH., June 8, 1987, at 66.

5. Johnson, U.S. Considers Compensation in Airbus Case, N.Y. Times, July 5, 1988, at 1, col. 2.

6. A Prudent Navy Once-Over on Safety, Chicago Tribune, Nov. 17, 1989, at 26, col. 1.

7. May, Navy Jet Hits Atlanta-Area Apartments: Toll Unknown, L.A. Times, Nov. 10, 1989, at 4 , col. 3 .

8. Kutzler and Kutzler, The Army's Silence On Accidental Death, N.Y. Times, Feb. 9, 1990, at A19, col. 2 (letter to editor).

9. 483 U.S. 669,709 (1987).

10. 816 F.2d 1417, 1424 (10th Cir. 1987).

11. 108 S. Ct. 2510 (1988).

12. The term "military security establishment" refers to the Department of Defense as well as other governmental agencies and private organizations with responsibility for weapons development and the use of force, including the Central Intelligence Agency, the Department of Energy, and private defense contractors. 
Standing at the vanguard of "national security" law, 13 these three decisions elevate the task of preparing for war to a level beyond legal

13. An underlying motive of this Article is to establisly the existence of a body of law known as "national security law" and to lielp define its parameters. The last decade witnessed a veritable explosion of cases and controversies involving the military and national security. In addition to the three cases discussed here, other cases imvolving tort accountability include Umited States v. Jolinson, 481 U.S. 681 (1987) (FAA immune from Federal Tort Claims Act suit by widow of coast guard pilot allegedly directed by FAA flight navigators into a mountainside); In re "Agent Orange" Prod. Liab. Litig., 818 F.2d 187 (2d. Cir. 1987), cert. denied, 454 U.S. 1128 (1988) (first in series of cases involving tort claims against United States and Agent Orange manufacturers arising from servicemen's exposure to defolliant in Vietnam); and Hart v. United States, 1990 U.S. App. Lexis 2779 (4th Cir. 1990) (government efforts to identify deceased personnel in Vietnam are discretionary functions immune from liability for infliction of emotional distress). Similar concerns regarding national security have arisen in constitutional actions for damages. Plaintiffs have brought a growing number of first amendment claims against the government since the Supreme Court's decision of New York Times Co. v. United States, 403 U.S. 713, 714 (1971) (denying government an mjunction against newspapers' publication of plans showing that American involvement in the Vietnam War liad antedated the Gulf of Tonkin Resolution; government failed to mect its "lieavy burden" of showing justification for prior restraint on expression). More recently, in Snepp v. United States, 444 U.S. 507, 516 (1980), and United States v. Morison, 604 F. Supp. 655, 664 (D. Md.), appeal dismissed, 774 F.2d 1156 (4tly Cir. 1985), cert. denied, 109 S. Ct. 259 (1988), the judiciary lias explored the balance between first amendment rights and the need for secrecy in national security matters. Very recently, in United States v. Snepp, 1990 U.S. App. Lexis 2730 (4tll Cir. 1990), the issue of prepublication review was litigated. Access to national security information under the Freedom of Information Act was litigated and limited in CIA v. Sims, 471 U.S. 159, 177 (1985); cf. Jolın Doe Agency v. John Doe Corp., 110 S. Ct. 471 (1989) (holdmg routine Pentagon audits not accessible under FOIA if tley take on law enforcement significance). Plaintiffs liave made fifth amendment claims for being denied security clearances (often because of their sexual preferences). See Carlucci v. Doe, 109 S. Ct. 407, 413 (1988) (Secretary of Defense has authority to terminate National Security Agency employee who engaged in lomosexual relationships with foreigu nationals); Webster v. Doe, 486 U.S. 592 (1988) (fifth amendment due process and equal protection claims of CIA employee allegedly terminated because of homosexuality held subject to judicial review); Department of Navy v. Egan, 484 U.S. 518, 530 (1988) (Merit System Protection Board without autlority to review substance of revocation of security clearance leading to employee's discharge); Dubbs v. CIA, 866 F.2d 1114, 1120 (9th Cir. 1989) (reversing summary judgment for CIA when employee alleged agency unconstitutionally discriminates against lomosexuals in security clearance determinations); High Tech Gays v. Defense Indus. Sec. Clearance Office, 668 F. Supp. 1361, 1377 (N.D. Cal. 1987) (equal protection violated by Department of Defense policy of subjecting lesbian and hoinosexual applicants for secret and top secret security clearances to expanded investigations because of sexual orientation). Other fifth amendment claims have cliallenged unsuccessfully a denial of the riglit to travel because of national security concerns. See Regan v. Wald, 468 U.S. 222, 244 (1984) (upliolding statute granting President autlority to prevent travel to Cuba); Haig v. Agec, 453 U.S. 280, 309 (1981) (uplolding statute allowing Secretary of State to revoke citizen's passport when citizen takes actions likely to cause damage to national security interests); Zemel v. Rusk, 381 U.S. 1, 17-18 (1965) (upholding statute allowing Secretary of State to refuse validation of passports for travel to Cuba). But see Kent v. Dulles, 357 U.S. 116, 130 (1958) (finding Secretary of State was not authorized to restrict freedom to travel by denying passports to citizens on basis of alleged Communist beliefs). The extent of fourtl amendment protections in the face of alleged "national security" concerns was raised in Mitchell v. Forsytli, 472 U.S. 511, 535 (1985). See, eg., Ellsberg v. Mitchell, 709 F.2d 51, 52 (D.C. Cir. 1983), cert. denied, 465 U.S. 1038 (1984) (constitutional tort action brouglit against former attorney general and otlers by persons exposed to warrantless electronic surveillance). The prospect of on-site inspection called for by the Intermediate Range Nuclear Forces Treaty of 1987 (INF) as well as by the proposed Chemical Weapons Convention may raise additional fourtli amendment 
accountability. They suggest that determinations of both the ends and the means of national security are inherently above the law and hence unreviewable regardless of the legal riglits transgressed by these determinations. This conclusion signals a dangerous abdication of judicial responsibility. The very underpinnings of constitutional governance are threatened by those who contend that the rule of law weakens the execution of military policy. Their argument-that because our adversaries are not restricted by our Constitution, we should become more like our adversaries to secure ourselves-cannot be sustained if our tradition of adlierence to the rule of law is to be maintained. To the contrary, the judiciary must be willing to demand adlerence to legal principles by assessing responsibility for weapons decisions. This Article posits that judicial abdication in this field is not compelled and certainly is not desirable. The legal system can provide a useful check against dangerous military action, more so than these three opinions would suggest. The judiciary must rigorously scrutinize military decisions if our 18th century dream of a nation founded in musket smoke is to remain recognizable in a millennium ushered in under the mushroom cloud of thermonuclear holocaust.

History shows that serious consequences ensue when the judiciary defers excessively to military authorities. Perhaps the most celebrated precedent for the deference to military discretion reflected in these recent decisions is the Supreme Court's 1944 decision in Korematsu v. United

concerns. See Tanzman \& Kellman, Legal Implementation of the Chemical Weapons Convention: Integrating International Security with the Constitution, 22 (2) N.Y.U. J. OF INT'L LAW \& PoL. (forthcoming 1990). As will be discussed at length below, there is a growing body of law under the War Powers Act involving direct challenges of the President's authority as Commander in Chief. The role of treaty law in regulating the development of new weapons systems has been addressed in the dispute over the legality of testing the Strategic Defense Initiative under the Anti-Ballistic Missile Treaty of 1972. See, e.g., Graham, SDI and "The Common Defense," 15 J. LEGIS. 115 (1989); Harbour, The ABM Treaty, New Technology and the Strategic Defense Initiative, 15 J. LEGIS. 119 (1989). Parties litigated the extent to which national security concerns might limit the discussion of environmental impact in a statement required by the National Environmental Policy Act in Weinberger v. Catholic Action, 454 U.S. 139 (1981) (Congress intended the public interest in federal agency compliance with NEPA to give way to government's need to preserve military secrets). See also Finamore, Regulating Hazardous and Mixed Waste at Department of Energy Nuclear Weapons Facilities: Reversing Decades of Environmental Neglect, 9 HARV. ENVTL. L. REV. 83, 87-104 (1985) (describing the evolution of the regulatory scheme for managing hazardous and mixed waste of DOE nuclear weapons facilities, and analyzing current DOE practices); Comment, The Application of NEPA to Nuclear Weapons Production, Storage, and Testing: Weinberger v. Catholic Action of Hawaii/Peace Education Project, 11 EnVTL. AFF. L. REv. 805, 811-14 (1984). The Iran-Contra affair demonstrated the importance of the question of accountability for the formulation and execution of military security policy. See, e.g., Jenkins \& Brink, The National Security Council and the Iran-Contra Affair, $18 \mathrm{GA}$. J. INT'L \& COMP. L. 19, $40-44$ (1988) (discussing the consequences of placing authority for the direct contact of foreign policy initiatives in the hands of the NSC staff). Of course, the trial of Oliver North and John Poindexter has added an enormous chapter to the role of the courts in matters pertaining to national security. 
States. ${ }^{14}$ Korematsu involved the conviction of an American citizen of Japanese descent for violating a wartime exclusion order against all persons of Japanese ancestry. That order, issued after Japan's attack on Pearl Harbor, declared that "the successful prosecution of the war requires every possible protection against espionage and against sabotage to national-defense material, national-defense preımises, and national-defense utilities."15 Justice Hugo Black's opinion for the Court, upholding the exclusion order and Korematsu's conviction, stressed the hardships occasioned by war and held that "the power to protect must be commensurate with the threatened danger." 16

Justice Murphy's dissent from this shameful abdication of responsibility presaged the thesis of this Article:

In dealing with matters relating to the prosecution and progress of a war, we inust accord great respect and consideration to the judgments of the military authorities who are on the scene and who have full knowledge of the military facts. The scope of their discretion must, as a matter of necessity and coinmon sense, be wide. And their judgments ought not to be overruled lightly by those whose training and duties ill-equip them to deal intelligently with matters so vital to the physical security of the nation.

At the same time, however, it is essential that there be definite limits to military discretion, especially where martial law has not been declared. Individuals must not be left impoverished of their constitutional rights on a plea of military necessity that has neither substance nor support. Thus, like other claims confficting with the asserted constitutional rights of the imdividual, the military claim must subject itself to the judicial process of having its reasonableness determined and its conflicts with other interests reconciled. "What are the allowable limits of military discretion, and whether or not they have been overstepped in a particular case, are judicial questions."

The judicial test of whether the Government, on a plea of military necessity, can validly deprive an individual of any of his constitutional rights is whether the deprivation is reasonably related to a public danger that is so "immediate, imminent, and impending" as not to admit of delay and not to permit the intervention of ordinary constitutional processes to alleviate the danger. ${ }^{17}$

The three principal decisions that this Article examines prove that the judiciary in recent times has not sufficiently heeded Justice Murphy's warning. Indeed, the unquestioned deference to the military security establishment contained in these decisions stands as this generation's moral equivalent of Korematsu. As in the Korematsu case, the courts that re-

14. 323 U.S. 214 (1944) (Korematsu I).

15. Id. at 217 (quoting Exec. Order No. 9066, 3 C.F.R. 1092 (1938-1943)).

16. Id. at 220 .

17. Id. at 233-34 (citations omitted). 
viewed these weapons testing cases permitted gross injuries to go uncoinpensated in the face of the military security establishment's claiun of "military necessity" as a defense. Yet, whereas Korematsu undeniably is a blot on American law, ${ }^{18}$ the three decisions discussed in this Article are not even "justified" by wartime crisis and involved physically greater injuries than those suffered by Japanese descendants incarcerated during World War II. Perhaps inost important is that these weapons testing decisions, hike Korematsu, confer sensitivc strategic value on highly questionable military activities and thus shroud patently dangerous conduct from legal challenge.

The issues that fraine this Article are essential to the future of constitutional governance: (1) When, if ever, should military activity be subject to legal scrutiny? and (2) What is the authority of the judiciary to exercise jurisdiction over military decisions? ${ }^{19}$ Although this Article presents only three cases, which theinselves address only the narrow issue of tort accountability for weapons testing, the three cases chosen provide explicit demonstrations of how the scope of judicial review of military discretion has undergone radical contraction. These cases portend a new and far-reaching doctrine that could replace legal protections with the caprice of sheer military might, justified only by inflated assertions of "national security." Although this area uniquely calls on the courts to decide controversies by reference to formal criteria and subject to the limits of reasonableness, the three cases discussed below reveal an abject judiciary unwilling to assert its proper role.

Part I of this Article traces the case law that has considered claims against the military and the proper scope of nilitary review. ${ }^{20}$ It deinon-

18. The meaning of the Korematsu decision to this generation was perhaps best summarized by District Judge Patel in Korematsu v. United States, 584 F. Supp. 1406, 1420 (N.D. Cal. 1984) (Korematsu II):

As historical precedent, it stands as a constant caution that in times of war or declared military necessity our institutions must be vigilant in protecting constitutional guarantees. It stands as a caution that in times of distress the shield of military necessity and national security must not be used to protect governmental actions from close scrntiny and accountability. It stands as a caution that in times of international hostility and antagonisms our institutions, legislative, executive and judicial, must be prepared to exercise their authority to protect all citizens from the petty fears and prejudices that are so easily aroused.

Id.

Congress did approve legislation granting restitution to those interned. See Restitution for World War II Internment of Japanese-Americans and Aleuts Act, 50 U.S.C.A. App. $\$$ 1989-1989d (West Supp. 1989).

19. As Professors Edgar and Schmidt have recently asked: "How can those who would shape our institutions respond to the threats and complexity of the modern world, and continue to respect our constitutional traditions of separation of powers and of informed freedom of expression on issues critical to democratic governance?" Edgar \& Schmidt, Curtiss-Wright Comes Home: Executive Power and National Security Secrecy, 21 HARV. C.R.-C.L. L. REv. 349, 350 (1986).

20. See infra notes $24-65$ and accompanying text. 
strates that the three weapons testing cases discussed herein are on the leading edge of a judicial trend toward conclusions of nonjusticiability on all matters reinotely involving military security. Parts $\mathrm{II},{ }^{21} \mathrm{III},{ }^{22}$ and IV $^{23}$ discuss in separate detail United States v. Stanley, Allen v. United States, and Boyle v. United Technologies. A brief conclusion then develops the important distinction between judicial deference and judicial abdication in the context of military security policy.

\section{Doctrinal Bases of Deference to the Military}

Either a civilian or a serviceman suffering injuries from military activities can bring a tort claim for damages against either a branch of government or a private party. The claim may allege a violation of constitutional rights or state statutory rights. ${ }^{24}$ In any event, the claim must overcoine the defense of sovereign immunity. ${ }^{25}$ In the absence of a statutory waiver of immumity, therefore, recovery of damages ${ }^{26}$ for the tortious actions of federal officials is limited to a suit against the official im his or her mdividual capacity, ${ }^{27}$ or mtroduction of a private bill in

21. See infra notes $66-117$ and accompanying text.

22. See infra notes $118-70$ and accompanying text.

23. See infra notes 171-97 and accompanying text.

24. The distiction between constitutional torts and common law torts is not without vexing and currently unresolved questions. Whether hability for constitutional torts should go as far as hability under the common law is a difficult question to answer because the measure of responsibility for government behavior may be different than that for individual tort hability. See Whitman, Government Responsibility for Constitutional Torts, $85 \mathrm{MrCH}$ L. REv. 225, $230-48$ (1986).

25. Sec generally Currie, Sovereign Immunity and Suits Against Government Officers, 1984 SuP. CT. REv. 149; Engdahl, Immunity and Accountability for Positive Governmental Wrongs, $44 \mathrm{U}$. CoLo. L. REv. 1 (1972); Jaffe, Suits Against Governments and Officers: Sovereign Immunity, 77 HARV. L. REv. 1 (1963); Note, Rethinking Sovereign Immunity After Bivens, 57 N.Y.U. L. Rev. 597 (1982).

A private contractor cannot claim sovereign immunity directly. According to the Boyle decision discussed infra, however, immunity may be extended to private contractors so as to prevent the costs of liability from being passed on to the government.

26. Although the doctrine of sovereign immunity does not bar judicial review of federal admmistrative action otherwise subject to judicial review, Admimistrative Procedure Act of 1976, 5 U.S.C. $\S 702$ (1988), the doctrine has retained its force regarding actions at law for damages. Edelman v. Jordan, 415 U.S. 651, 663 (1974).

27. Such an action would itself be problematic because of the principle that government officials performing discretionary functions "generally are shielded from liability for civil damages insofar as their conduct does not violate clearly established statutory or constitutional rights of which a reasonable person would have known." Harlow v. Fitzgerald, 457 U.S. 800,818 (1982). In Mitchell v. Forsyth, 472 U.S 511, 520-21 (1985), the Supreme Court held that status as a Cabinet officer is not in itself sufficient to invest absolute immunity, nor does the nature of the Attorney General's national security functions support absolute, rather than qualified, immunity. See Bermann, Integrating Governmental and Officer Tort Liability, 77 CoLuM. L. REv. 1175, 1180 (1977); Woolhandler, Patterns of Official Immunity and Accountability, 37 CASE W. REs. L. REv. 396, $477-83$ (1987); Note, Intramilitary Immunity and Constitutional Torts, 80 MrCH. L. REv. 312, 320 (1981). 


\section{Congress. ${ }^{28}$}

The Federal Tort Claims Act ${ }^{29}$ (FTCA) is a statutory waiver of sovereign immunity that permits suits against the United States for injuries caused by "the negligent or wrongful act or omission of any employee of the Government while acting within the scope of his office or employment, under circumstances where the United States, if a private person, would be liable to the claimant in accordance with the law of the place where the act or omission occurred."30 This right of recovery is limited by thirteen exceptions, two of which limit claims arising out of military activities: (1) the discretionary functions exception, ${ }^{31}$ and (2) the exception for activities mcident to military service. ${ }^{32}$ Judicial application of these exceptions to the three weapons testing controversies discussed lerein forms the focus of this Article.

\section{A. The Discretionary Function Exception}

The basic purpose of the discretionary function exception is "to allow a government official the freedoin to choose a course of conduct without the threat of governmental liability lurking in the background." 33 However, this exception would categorically reinstate sovereign immunity unless there were express limits to the grant of discretion since most conscious acts involve some degree of choice. That dilemma has received considerable attention ${ }^{34}$ from which criteria of discretion lave been forged. As interpreted, the exception focuses on whether the

28. The legislative history of the FTCA demonstrates congressional concern with the massive number of private rehief bills which occupied an undue amount of attention. See H.R. REP. No. 1287, 79th Cong., 1st Sess. 2 (1945).

29. Act of Aug. 2, 1946, ch. 753, tit. IV, 60 Stat. 812,842 (principally codified in 28 U.S.C. $\S \S 1346(b), 2671-2680$ (1982 \& Supp. V 1987)).

30. 28 U.S.C. $\$ 1346(b)$ (1982).

31. The provisions of this chapter and section $1346(\mathrm{~b})$ of this title shall not apply to ... the exercise or performance or the failure to exercise or perform a discretionary function or duty on the part of a federal agency or an employec of the Government, whether or not the discretion involved be abused. " Id. $\$ 2680$ (a).

32. The FTCA specifically excepts "any claim arising out of the combat activities of the military or naval forces . . . during time of war." Id. $\S 2680(\mathrm{j})$.

33. Harris \& Schnepper, Federal Tort Claims Act: Discretionary Function Exception Revisited, 31 U. Miami L. Rev. 161, 188 (1976).

34. Among the more recent and noteworthy commentaries on the discretionary function exception are: Kratzke, The Convergence of the Discretionary Function Exception to the Federal Tort Claims Act with Limitations of Liability in Common Law Negligence, 60 ST. JoHN's L. REV. 221 (1986); Ogden, Entity Liability Under the Federal Tort Claims Act: An Analysis and a Proposal for Changes in the Law, 15 U.C. DAVIS L. REv. 907, 938-48 (1982); Zillman, The Changing Meaning of Discretion: Evolution in the Federal Tort Claims Act, 76 MIL. L. Rev. 1 (1977); Note, The Discretionary Function Exception: Is It a Bar to Federal Jurisdiction?, 1983 UTAH L. REV. 117. For further discussion of the discretionary function exception, see infra Part III and accompanying notes. 
decisionmaking process involves policy considerations. Whether courts should recognize the government's discretionary function immunity nuust be decided in each case by balancing the government's need to function agamst the right of individuals to legal redress for their injuries.

At the core of the discretionary function exception is a recognition that regulatory decisions, such as promulgating rules and issuing hicenses or permits, cannot give rise to a private cause of action without substantially interferimg with the conduct of government. Furthermore, planning decisions that call for a balancing of financial, political, economic, and social effects may not be subject to judicial review. Although the government's decision to undertake a particular course of conduct may be protected, however, execution of that decision in a manner that deviates from properly authorized instructions can result in civil liability. ${ }^{35}$ Liability turns not on the government official's status (though that may be factually significant) but on the nature and quality of the decision itself-whether it included the type of regulatory or planning activity that is the essence of policy formation. Thus, in Peterson v. United States, ${ }^{36}$ the court held that the discretionary function exception did not immunize the government from a farmer's clann of mjuries from a B-52 bomber fiying too low over his farm:

The planming level of the Air Force training and evaluation missions, which would include the developinent of the route for the mission at issue here, is protected within this discretionary function exception. Nevertheless, the discretionary function exception does not protect the United States from hability for operational negligence in carrying out such a mission. The Umited States is not protected if the pilot operating the B-52 which flew over Peterson's farm was negligent in imiplementing the policy decisions made by Government officials. ${ }^{37}$

The discretionary function exception thus should clarify the distniction between the formulation of policy by high-ranking officials and the routine iniplenientation of policy by subordinates. Only policy decisions should be exempt; where the alleged misconduct involves the negligent acts of an agent, the discretionary function exception does not prevent the imiposition of liability on that official. ${ }^{38}$

35. Ward v. United States, 471 F.2d 667, 670 (3rd Cir. 1973) (stating that "ordering an army maneuver is a discretionary function, but the negligent operation of an army vehicle during such a maneuver is not"); see also Driscoll v. United States, 525 F.2d 136, 139 (9th Cir. 1975) (no immunity from liability for injuries to civilian struck by an automobile on an air force base since decision not to install appropriate warning devices or crosswalks was made at operational level).

36. 673 F.2d 237 (8th Cir. 1982).

37. Id. at 240 (citations omitted).

38. The Supreme Court recently held in Berkovitz for Berkovitz v. United States, $108 \mathrm{~S}$. Ct. 1954, 1960 (1988): "[T]he exception was designed to cover not all acts of regulatory agencies and their employees, but only such acts as are 'discretionary' in nature....The discretionary function ex- 


\section{B. The Feres Exception}

A series of Supreme Court decisions beginning with Feres $v$. United States ${ }^{39}$ has developed the exception for servicemen's injuries incurred incident to military service. Tort immunity stenis from the concern that suits by servicemen would threaten military discipline and enipower the courts to interfere with the military's chain of command. ${ }^{40}$ The Feres doctrine is based on the need to preserve military discipline; to litigate claims involving the management of the military and the control of service personnel would impede the immediate obedience to orders required in the military environment. ${ }^{41}$

Many questions have arisen under Feres concerning whether the mere status of the victim as a servicenian bars any and all recovery, ${ }^{42}$ or whether the immunity may apply to acts of civilian agencies of the government. Recently, the Supreme Court extended the scope of application for Feres suits against civilian agencies. In United States $v$. Johnson, 43 immunity was upheld against a wrongful death claim by a Coast Guard pilot's widow who alleged that Federal Aviation Adninistration (FAA) air traffic controllers neghigently caused the pilot's aircraft to crash. The Court applied the three Feres rationales despite the FAA's civilian status: (1) the federal relationship between the government and servicemen; (2) the existence of statutory disability and death benefits; and (3) the potential that servicemen's suits against the government could disrupt inilitary discipline. Johnson suggests that it is not the military status of the agency which is essential for immunity; rather, the immunity nuay be extended where necessary to prevent suits based on service-related injuries.

Courts have extended the logic of Feres to bar suits by servicemen not only against the government but also against private military contractors. In Stencel Aero Engineering Corp. v. United States, ${ }^{44}$ the Court rejected a contractor's claim of indemnification from the government for damages paid to a member of the National Guard. In the Agent Orange

ception applies only to conduct that involves the permissible exercise of policy judgment." Thus, this exception tends to protect higher level officials while leaving lower level officials uncovered.

39. 340 U.S. 135 (1950). More recently, the Court reaffirmed the Feres doctrine in United States v. Shearer, 473 U.S. 52 (1985) (immunity upheld against soldier's heir's claims that negligent discharge of murderer from military prison was proximate cause of death; claims went directly to management of military, calling into question basic clioices about discipline, supervision, and control of servicemen).

40. United States v. Brown, 348 U.S. 110, 112 (1954).

41. Lockheed Aircraft Corp. v. United States, 460 U.S. 190 (1983).

42. Compare Broudy v. United States, 661 F.2d 125 (9th Cir. 1981) with Lombard v. United States, 690 F.2d 215 (D.C. Cir. 1982).

43. 481 U.S. $681,691-92$ (1987).

44. 431 U.S. 666 (1977). 
litigation, ${ }^{45}$ the Court inverted the logic of Stencel Aero Engineering to grant private contractors a defense against servicemen's product liability claims if they proved that: (1) the government established the specifications for the product; (2) the product complied with the government's specifications in all material respects; and (3) the government knew as much as, or more than, the contractor about the hazards accompanying use of the product. According to the Court's reasoning:

The purpose of a government contract defense in the context of this case is to permit the government to wage war in whatever manner the government deems advisable, and to do so with the support of suppliers of military weapons. Considerations of cost, time of production, risks to participants, risks to third parties, and any other factors that might weigh on the decisions of whether, when, and how to use a particular weapon, are uniquely questions for the military and should be exenipt from review by civilian courts. ${ }^{46}$

The Agent Orange case left open the question of how explicit government specifications inust be to support tlie immunity: Is mere approval of contractor specifications sufficient, or does the immunity require compulsory instructions that the contractor must obey? ${ }^{47}$

45. In re "Agent Orange" Prod. Liab. Litig., 534 F. Supp. 1046, 1057 (E.D.N.Y. 1982), cert. denied, 465 U.S. 1067 (1984).

46. Id. at 1054 n.1.

47. Compare Shaw v. Grumman Aerospace Corp., 778 F.2d 736 (11th Cir. 1985) (contractor must show either no or minimal participation in design or must have notified military of risk and provided alternative designs that military rejected in order to avoid liabihity); Trevino v. General Dynamics Corp., 626 F. Supp. 1330 (E.D. Tex. 1986) (defendant liable because it, not government, ultimately "established reasonably precise specifications" for diving system that caused injuries), cert. denied, 110 S. Ct. 327 (1989) and Johnston v. United States, 568 F. Supp. 351 (D. Kan. 1983) ("government contract defense only applies where the injury-causing aspect of the product was mandated by the contract") with Tozer v. LTV Corp., 792 F.2d 403 (4th Cir. 1986) (contractor's defense is not waived by contractor participation because allowing defense to be waived would put contractors between fear of hability and desire to provide needed imformation to government; if government genuinely participated in design, contractor has a defense), cert. denied, 108 S. Ct. 2897 (1988); Dowd v. Textron, Inc., 792 F.2d 409 (4th Cir. 1986) (explicitly adopting Tozer rule); Bynum v. FMC Corp., 770 F.2d 556 (5th Cir. 1985) (to avoid liability, military contractor must prove that government established reasonably precise specifications, and contractor warned government about dangers of specifications known to contractor but not government); In re Air Crash Disaster at Mannheim, Germany on Sept. 11, 1982, 769 F.2d 115 (3d Cir. 1985) ("government contractor defense is available despite contractor's participation in development of the design, so long as the government has approved the design after a substantial review of the specifications"), cert. denied, 474 U.S. 1082 (1986); Tillett v. J.I. Case Co., 756 F.2d 591 (7th Cir. 1985) (declined to adopt mle requiring compulsion by government to execute contract as element of government contractor defense); Koutsoubos v. Boeing Vertol, 755 F.2d 352 (3d Cir. 1985) (rejected coinpulsion as element of governinent contractor defense, instead found sufficient government participation to bring case within Agent Orange rule), cert. denied, 474 U.S. 821 (1985) and McKay v. Rockwell Int'l Corp., 704 F.2d 444 (9th Cir. 1983) (government contractor not liable if the government "established, or approved, reasonably precise specifications for the allegedly defective military equipment" and if the contractor warned the governmeut about the dangers involved in the use of equipment known to supplier but not United States), cert. denied, 464 U.S. 1043 (1984). The reader should note that this 
It is not the purpose of this Article to challenge either the discretionary function exception or the Feres incident-to-service exception. Each exception is based on reasonable considerations regarding the limits of judicial authority and generally has been applied conservatively in appropriate situations. In a sense, these two exceptions illustrate that judicial caution is appropriate when courts review conduct at opposite extremes of the military command spectrum: The discretionary function protects the highest and most abstract functions of government-the formulation of policy by semior officials; and the "incident to service" exception protects the most specific military commands-the battlefield orders of an officer to his troops. The problem with these exceptions is not their application im appropriate circumstances, but rather if the exceptions are allowed to expand, they eventually will meet and immunize all activities bearing the military's imprimatur. There is a vast and important range of potentially tortious military conduct between the extremes of discretionary policymaking and commands incident to service. Each case discussed below arguably falls into this middle range because the plaintiff's claim of injury challenges neither military policy nor the commands of superior officers; instead, the challenge in each case is against the manner that a particular military program was executed.

\section{Limiting the Exceptions}

This Article's purpose is to suggest that the courts have improperly extended the language of both FTCA exceptions in the three weapons testing cases discussed herein to render tort claims against the military nonjusticiable. Indeed, this Article asserts that the weapons testing cases represent flawed judicial efforts to apply the nonjusticiability considerations undergirding the political question doctrine to these disputes by invoking either the FTCA discretionary function or the incident-to-service exception. This doctrinal shift from the constitutional dimensions of the political question doctrine with its judicially developed criteria ${ }^{48}$ to a

issue was at the heart of the argument, but not the decision, in Boyle v. United Technologies Corp., 487 U.S. 500 (1988) (discussed infra Part IV). The development of the military contractor defense and an analysis of its application in the context of modern weapons procurement policies was presented in Kellman, De-Coupling the Military/Industrial Complex-The Liability of Weapons Makers for Injuries to Servicemen, 35 CLEv. ST. L. REV. 351 (1987).

48. In Baker v. Carr, 369 U.S. 186, 217 (1962), Justice Brennan established six criteria for the political question doctrine:

Prominent on the surface of any case held to involve a political question is found a textually demonstrable constitutional commitment of the issue to a coordinate political department; or a lack of judicially discoverable and manageable standards for resolving it; or the impossibility of deciding without an initial policy determination of a kind clearly for nonjudicial discretion; or the impossibility of a court's undertaking independent resolution without expressing lack of the respect due coordinate branches of government; or an unusual need for unquestioning adherence to a political decision already made; or the potentiality 
reliance on the FTCA's open-ended exceptions to federal government liability-substantially broadens the range of military conduct that may be nonjusticiable.

Nonjusticiability based on prudential considerations regarding the possibility of unwarranted intrusion into military affairs beyond the scope of the judiciary's article III authority has been upheld in cases where properly authorized matters of national security policy directly relate to the international exercise of military force. ${ }^{49}$ The political question doctrine, itself higlily controversial, ${ }^{50}$ applied in this context reflects the judiciary's reluctance to interfere witl the legitimate exercise of military authority, due in part to the military's need for unchallenged loyalty in the face of external threats. ${ }^{51}$ Where a coinplainant challenges military policy, the doctrine asserts that responsibile officials may be lield accountable only in the political arena-judicial review of a claim alleging tort liability is therefore inappropriate. Yet this doctrine is limited by countervailing considerations that emphasize the importance of judicial review even of disputes with a political or military aspect. Even the Supreme Court's broadest application of the pohtical question doctrine to the military, Justice Burger's opinion in Gilligan v. Morgan, ${ }^{52}$ cautioned against an application of the doctrine that would preclude entirely legal accountability:

The ultimate responsibility for [the conposition, training, equipping, and control of the national guard] is appropriately vested in branches of government which are periodically subject to electoral accountability. It is this power of oversight and control of military force by

of embarrassment from multifarious pronouncements by various departments on one question.

49. See generally Tigar, Judicial Power, The "Political Question Doctrine" and Foreign Relations, 17 UCLA L. REV. 1135 (1970); Note, The Boland Amendments and Foreign Affairs Deference, 88 COLUM. L. REV. 1534 (1988).

50. Professor Bickel supported the "prudential" version of the political question doctrine based upon "the inner vulnerability of an institution which is electorally irresponsible." See Bickel, The Supreme Court 1960 Term-Forward: The Passive Virtues, 75 HARv. L. Rev. 40, 75 (1961). Professor Wechsler, on the other hand, limited the doctrine to cases in which "the Constitution has committed the determination of the issue to another agency of government than the courts." See Wechsler, Toward Neutral Principles of Constitutional Law, 73 HARv. L. REv. 1, 9 (1959). The weight of more recent scholarly commentary has advocated doing away with the doctrine altogether or at least severely limiting its application. See generally Champlin \& Schwarz, Political Question Doctrine and Allocation of the Foreign Affairs Power, 13 HoFsTRA L. REv. 215 (1985); Redish, Judicial Review and the "Political Question," 79 Nw. U.L. REv. 1031, 1059-61 (1985); Henkin, Is There a "Political Question" Doctrine?, 85 YALE L.J. 597, 622-24 (1976).

51. "[T] $]$ he very nature of executive decisions as to foreign policy is political, not judicial. ... They are decisions of a kind for which the Judiciary has neither aptitude, facilities nor responsibility and which has long been held to belong in the domain of political power not subject to judicial intrusion or inquiry." Chicago \& S. Air Lines v. Waterman S.S. Corp., 333 U.S. 103, 111 (1948).

52. 413 U.S. 1 (1973). 
elected representatives and officials which underlies our entire constitutional system ....

... In concluding that no justiciable controversy is presented, it should be clear that we neither hold nor imply that the conduct of the National Guard is always beyond judicial review or that there nnay not be accountability in a judicial forum for violations of law or for specific unlawful conduct by military persoimel. ${ }^{53}$

Application of the discretionary function and Feres exceptions to the weapons testing cases achieves the same result as application of the political question doctrine, but in unprecedented contexts. The effect is to radically expand the doctrinal bases for denymg legal redress to tort victims of military activity. Although the political question doctrine was not raised explicitly in any of the weapons testing cases discussed below, the metaplior of nonjusticiability helps to explain the decisions. The courts used the discretionary function and incident-to-service exceptions as rubrics for refusing to entertain the plaintiffs' claims of tortious conduct by the military. These three decisions starkly assert the underlying rationale for political question nonjusticiability without considering the three limiting considerations set out below. Further, these decisions invoke nonjusticiability in statutory (rather than constitutional) contexts, in which the need for prudential deference should be, and generally has been, left for congressional deterinination. Thus, these three weapons testing decisions, in the unprecedented context of federal tort litigation under the FTCA, exhibit a one-sided application of the political question doctrine that neglects the countervailing need for judicial review.

Application of the political question doctrine involves three principles. First, the protected conduct inust be of constitutional significance-i.e., only the decisions of Congress or high ranking Executive Brancl officials wonld be nonjusticiable. ${ }^{54}$ Thus, not all cases with polit-

53. Id. at 11-13.

54. Decisions concerning the President's war power explicitly demonstrate this point. See generally W. Reveley, War Powers of the President and Congress: Who Holds the ARRows AND Olive BraNch? 206-12 (1981). In Holtzman v. Schlesinger, 484 F.2d 1307, 1310 (2d Cir. 1973), cert. denied, 416 U.S. 936 (1974), a challenge against the bombing and invasion of Cambodia was held to involve "questions of fact involving military and diplomatic expertise not vested in the judiciary, which make the issue political." See also Atlee v. Laird, 347 F. Supp 689 (E.D. Pa.), affd sub nom. Atlee v. Richardson, 411 U.S. 911 (1973). In Lowry v. Reagan, 676 F. Supp. 333, 340 (D.D.C. 1987), the determination of whether the introdnction of United States military forces into the Persian Gulf constituted "imminent involvement in hostilities ... would risk the potentiality of embarrassment (that would result) from multifarious pronouncements by various departments on one question" and "could impact on statements by the Executive that the United States is neutral in the Iran-Iraq war." See also Sanchez-Espinoza v. Reagan, 568 F. Supp. 596, (D.D.C. 1983), aff'd on other grounds, 770 F.2d 202 (D.C. Cir. 1985). For a thorough discussion of the Sanchez case and the application of the political question doctrine, see Comment, Challenging Covert War: The Politics of the Political Question Doctrine, 26 HARv. INT'L L.J. 155 (1985). Even as to issues other than war powers, the political question doctrine has been successfully invoked nearly always in matters that 
ical overtones are thereby rendered nonjusticiable. A "political question" challenge must be against the conduct of a semior Executive official who is authorized, either by article II of the Constitution or by specific congressional enactment, to act for the United States im regard to war or foreign relations. ${ }^{55}$

Second, the constitutional allocation of authority to either Congress or the Executive Branch must be manifest for the Court to invoke political question deference. Altlougl the judiciary sliould abjure review of the government's final policy decisions, the judiciary must nevertleeless review the preliminary question of whether in fact policy decisions were made. As discussed above in the context of the discretionary function exception, ${ }^{56}$ this consideration draws on the distinction between injuries that result from a policy clioice and injuries resulting from execution of policy at the operational level.

involve foreign policy. Thus, in Smith v. Reagan, 844 F.2d 195 (4th Cir.), cert. denied, $109 \mathrm{~S}$. Ct. 390 (1988), the doctrine was invoked to bar a declaratory judgment action against President Reagan by relatives of missing Vietnam veterans who sought independent judicial inquiry as to the status of missing servicemen. The court of appeals stated that

a charge that a foreign government has 'unjustly deprived' an American citizen of hiberty is likely to have far-reaching and unforeseeable effects on the conduct of foreign relations.... Congress therefore gave great discretion to the President in making, or refraining from making, such a charge and choosiug the actions to be taken after such a charge is made.

Id. at 198-99. Similarly, the decision by Secretary of State Shultz to close the Washington Office of the Palestine Information Office was held to be a pohicy question firmly lodged in the political branches of government: "The executive branch acted in this case in the precise realm in which the Constitution accords it greatest power. The authority of the executive branch, always great in the foreign policy field, is at its apex when it acts, as here, pursuant to an express congressional authorization." Palestine Information Office v. Shultz, 853 F.2d 932, 934 (D.C. Cir. 1988).

55. As a New York district court recently held in Greenham Woinen Against Cruise Missiles v. Reagan, 591 F. Supp. 1332, 1338 (S.D.N.Y. 1984), aff'd per curiam, 755 F.2d 34 (2d Cir. 1985), an action to enjoin the deployment of cruise missiles in England was nonjusticiable:

The courts are simply incapable of determining the effect of missile deployment on world peace. ... Questions like how to ensure peace, how to promote prosperity, what is a fair utilization and distribution of economic resources are examples of questions that must be decided by the fair, sound, seasoned and inature judgments of men and women responsive to the common good. The power to make these deterininations is therefore appropriately allocated to the political branches.

Id. For an intriguing comparison, sec Operation Dismantle Inc. v. The Queen, [1985] 1 S.C.R. 441, 451 in which the Canadian Supreme Court stated:

[T] he infringement of the appellants' rights are founded on the premise that if the Canadian Government allows the United States Government to test the cruise missile system in Canada, then there will be an increased risk of nuclear war. Such a clain can only be based on the assumption that the result of all of the various foreign powers' reactions to the testing of the cruise missile in Canada will be an increased risk of nuclear war.

Since the foreign policy decisions of independent and sovereign nations are not capable of prediction, on the basis of evidence, to any degree of certainty approaching probability, the nature of such reactions can only be a matter of speculation; the causal link between the decision of the Canadian Government to permit the testing of the cruise and the results that the appellant alleges could never be proven.

Id.

56. See supra notes 33-38 and accompanying text. 
Third, in cases where nonjusticiability is based on the judiciary's inability to inake factual determinations because they are beyond the judiciary's resources and expertise or would constitute an intrusion inpairing effective government administration, that inability inust be patent in recognition of the judiciary's procedures for dealing with sensitive information. This condition raises troubling issues regarding the judicial role in resolving complex and sensitive disputes. There is a strong presumption that the judiciary has the ability to make factual determinations when presented with a dispute over legal rights-to refuse to decide a case due to the sensitive pohtical information involved must be because of the overwhelming and obvious difficulties in ascertaining the truth in a particular case; mere concern about political sensitivities is not enough. The case precedents stress that the difficulty of determining facts must not swallow the necessary role of judicial review. In Langenegger $v$. United States, ${ }^{57}$ for example, claims that the United States was responsible for a program of agrarian reform in El Salvador that resulted in confiscation of plaintiffs' property were held justiciable:

The courts are often presented with questions which consider congressional or executive actions and purposes, and have managed to decide cases without putting the government in a fishbowl....

....

... While cases involving foreign affairs may make the courts uncomfortable, the Constitution mandates the role of the judiciary without regard to its comfort. ${ }^{58}$

These limitations on invoking the political question doctrine serve the important purpose of restricting nonjusticiability to a very select set of issues and draw a discermible line between deference and abdication.

Consider, by way of contrast to the three weapons testing decisions discussed herein, the court's willingness to hear the tort claim raised in De Arellano v. Weinberger, ${ }^{59}$ one of the inost important political question

57. 756 F.2d 1565 (Fed. Cir. 1985), cert. denied, 474 U.S. 824 (1985).

58. Id. at 1569-70. But see Crockett v. Reagan, 558 F. Supp. 893, 898 (D.D.C. 1982), affd per curiam, 720 F.2d 1355 (D.C. Cir. 1983), cert. denied, 467 U.S. 1251 (1984). The issue in Crockett was whether the President had to prepare a report, as contemplated by the War Powers Resolution, regarding United States' involvement in El Salvador. District Judge Green specifically held that this was not a political question in which the judiciary might interfere with Executive discretion in the foreign affairs field, but the issue was nevertheless nonjusticiable because of the difficulties of requisite factual determinations:

Even if the plaintiffs could introduce admissible evidence concerning the state of hostilities in various geographical areas in El Salvador where U.S. forces are stationed and the exact nature of U.S. participation in the conflict ...., the Court no doubt would be presented conflicting evidence on those issues by defendants. The Court lacks the resources and expertise .... to resolve disputed questions of fact concerning the military situation in El Id. Salvador.

59. 745 F.2d 1500 (D.C. Cir. 1984). 
cases decided in recent years. A United States citizen claimed that the United States Department of Defense, in building a large military facility for traiming Salvadoran soldiers on his cattle ranch in Honduras, had taken his property without due process of law in violation of the fiftl amendinent. ${ }^{60}$ The district court dismissed the complaint as nonjusticiable because the claim directly challenged the propriety of the' United States' military presence im Central Ainerica. ${ }^{61}$ The Court of Appeals for the District of Columbia Circuit reversed, explaining: "[P]laintiffs do not seek to adjudicate the lawfulness of the United States military presence abroad. Instead, they seek adjudication of the narrow issue whether the United States defendants nay run military exercises throughout the plaintiff's private pastures when their land has not been lawfully expropriated." 62 In contrast to disputes that cliallenged the propriety of U.S. policy in Central America, ${ }^{63}$ the court of appeals reasoned that the judiciary could resolve the factual disputes without exceeding its expertise or risking disclosure of sensitive and confidential communications.

Then-Judge Scaha, dissenting, characterized the plaintiff's claim as one requiring "direct court interference with a military operation being conducted abroad," since it sought an order that "would have substantial foreign policy consequences." 64 In response to Judge Scalia's objection, Judge Wilkey's majority opmion referred to the narrowness of the political question doctrine:

The Executive's power to conduct foreign relations free from the unwarranted supervision of the Judiciary cannot give the Executive carte blanche to trample the most fundamental liberty and property rights of this country's citizenry. The Executive's foreign relations prerogatives are subject to constitutional himitation....

... Affirmance of this dismissal on the ground that plaintiff's claims are political questions or an improper challenge to foreign af-

60. The Honduran government expropriated the land. The United States claimed that the facility belong to the Hondnran government.

61. 568 F. Supp. 1236, 1238 (D.D.C. 1983), aff'd, 724 F.2d 143 (D.C. Cir. 1983), rev'd, 745 F.2d 1500 (D.C. Cir. 1984).

62. 745 F.2d at 1512 .

63. In Committee of U.S. Citizens in Nicaragua v. Reagan, 859 F.2d 929, 935 (D.C. Cir. 1988), the court refused to enjoin the United States government's alleged failnre to abide by an International Court of Justice (ICJ) decision that ruled America's support of military actions by the "Contras" violated international law. Judge Mikva explicitly rejected application of the politieal question doctrine, but ruled that, on the merits, there is no basis in domestic law for enforcing the ICJ ruling:

[T] he key question is not simply whether the United States has violated any ... legal norms, but whether such violations ean be remedied by an American court or whether they can only be redressed on an international level. In short, do violations of international law have domestic legal consequences? ... Here, the alleged violation is the law that Congress enacted and that the President signed, appropriating funds for the Contras. When our government's two political branches, acting together, contravene an international legal norm, does this court have any authority to remedy the violation? The answer is "no ...." 64. De Arellano, 745 F.2d at 1561-62 (Scalia, J., dissenting). 
fairs powers would mean that virtually anything done by United States officials to United States citizens on foreign soil is nonjusticiable. This is not the law. 65

Judge Wilkey's assertion of limits to nonjusticiability demonstrates that until very recently Judge Scalia's broad use of the political question doctrine neither was nor should be the law. The De Arellano decision stands in opposition to each of the three weapons testing decisions discussed herein (two of which were authored by Justice Scalia). In each case, the judiciary refused to adjudicate injury claims of American citizens stemming from military activities during peacetime. None of these claims challenged international or pohtical activities that required senior Executive Branch approval or forced the judiciary to make exceptionally sensitive factual determinations. The limiting considerations inherent in the political question doctrine would not have counseled against judicial review. Instead of confronting those considerations directly, the courts in United States v. Stanley, Allen v. United States, and Boyle v. United Technologies formulated new doctrine to reach the same result with less justification. In comparison to De Arellano, the weapons testing decisions: (1) deny justiciability of challenges to the military's domestic peacetime activities; (2) erase nearly all specific criteria by which courts have determined a need for deference; and (3) reflect a judicial imprimatur on the strategic importance of weapons testing. Ironically, these decisions also denounce the judiciary's ability to do what courts normally do well-analyze specific facts under criteria honed by precedent-but affirm the judiciary's ability to assess risks, weigh values, and allocate costs. The result of this doctrinal devolution is that the scope of judicial review of military discretion has narrowed radically, thereby generating serious concerns that the military may transgress constitutional rights of Americans with impunity.

\section{UNITED STATES V. STANLEY}

During World War II, the Office of Strategic Services (OSS), the predecessor of the Central Intelligence Agency (CIA), began searching for a drug that could overcome the psychological defenses of enemy spies and precipitate their uninhibited disclosure of secret information. After experimenting with alcohol, barbiturates, peyote, scopolamine, niarijuana, mescaline, and cocaine, in the early 1950s the CIA settled on lysurgic acid diethylamide (LSD) because it had the potential of eliciting

65. Id. at 1515 . 
accurate information while leaving the subject with temporary amnesia. ${ }^{66}$ In addition, the CIA was concerned that the Soviet Umion and communist China might be developing LSD as an espionage weapon; the CIA therefore wanted its operatives to have had experience with LSD before being sent on sensitive overseas missions so that, if captured and drugged, they would not break down. ${ }^{67}$

CIA operatives realized that intense mental confusion could be produced by deliberately attacking a person along psychological hines. Of all the chemicals that caused mental derangernent, none was as powerful as LSD. Acid not only inade people extremely anxious, it also broke down the character defenses for handling anxiety. A skillful interrogator could exploit this vulnerability by threatening to keep an unwitting subject in a tripped-out state indefinitely unless he spilled the beans. This tactic often proved successful where others had failed. CIA documents indicate that LSD was einployed as an aid to interrogation on an operational basis from the mid-1950s through the early 1960 s. 68

In 1953, the CIA mitiated Operation MKULTRA under the direction of Richard Helms, then a high-ranking member of Clandestine Services. Although MKULTRA testing at first was limited to CIA personnel, subsequent projects involved the surreptitious administration of LSD to unwitting civilian subjects. ${ }^{69}$ Meanwhile, the Army Chemical Corps pursued widespread testing of LSD on nnsuspecting inilitary umits to determine the drug's effects on soldier performance. ${ }^{70}$ These tests rarely inet FDA standards for drug testing on humans ${ }^{71}$-indeed, im some instances no medical personnel were even present. ${ }^{72}$ In all, the

66. M. LeE \& B. ShLAIN, ACID DREaMs: The CIA, LSD, AND THE SiXTIES Rebellion 14 (1985) (citing Report of CIA Office of Scientific Intelligence, Potential New Agent for Unconventional Warfare (1954)).

67. "There was a legitimate concern in the early 1960s that hallucinogenic drugs, such as LSD, might be employed by our enemy against our troops (I might add that the possibility has not been discounted even now). At that time, immediate drng effects were studied and demonstrated in the national interest." Letter from Brig. Gen. Robert Bernstein, M.D., Assistant Surgeon General for Research and Development, to LTC William R. Jordan (Apr. 5, 1973), reprinted in Human-Use Experimentation Programs of the Department of Defense and Central Intelligence Agency: Hearings before the Subcomm. on Health of the Comm. on Labor and Public Welfare and the Subcomm. on Admin. Practice and Procedure of the Comm. on the Judiciary, 94th Cong., 1st Sess. 96 (1975) [hereinafter Human-Use Experimentation Hearings].

68. M. LEE \& B. ShLAIN, supra note 66, at 19.

69. See FinAl REPORT OF THE SELECT COMMITTEE to STUdy GoverNMENT OPERATIONS WITH Respect to INTElligence Activities, S. ReP. No. 755, 94th Cong., 2d Sess. bk. 1, at 389 (1976), noted in CIA v. Sims, 471 U.S. 159, 161-62 nn.1 \& 2 (1985).

70. M. LEE \& B. ShLAIN, supra note 66 , at 40.

71. Over a decade after Lieutenant Stanley's LSD experimentation, the Department of Defense and the Food and Drug Administration entered into a Memorandum of Understanding concerning Investigational Use of Drugs By The Department of Defense, 39 Fed. Reg. 231 (1974), reprinted in Human-Use Experimentation Hearings, supra note 67, at 8.

72. Human-Use Experimentation Hearings, supra note 67, at 121 (testinony of Mrs. Ray). 
Army Chemical Corps subjected nearly fifteen hundred military personnel to LSD experiments. ${ }^{73}$

\section{A. The Prima Facie Case}

In 1958, Master Sergeant James B. Stanley, a highly decorated veteran of the Korean War, volunteered to participate in an experimental program with the alleged purpose of testing methods of defense against chemical warfare attack, including the testing of various gas masks and protective clothing. During the course of clinical testing at Edgewood Arsenal in Aberdeen, Maryland, he unknowingly consumed four doses of LSD. Stanley claimed that he suffered from hallucinations and memory losses that eventually tore apart his career and marriage. Not until 1975, when the Army wrote Stanley requesting inforination from "volunteer participants" for a follow-up study on the effects of LSD, did Stanley learn the cause of his distress.

When his claims for compensation were denied by the Army and the CIA, Stanley filed suit under the FTCA alleging neghigence. ${ }^{74}$ The district court granted summary judgment for the governinent, reasoning that the Feres doctrine ${ }^{75}$ barred Stanley's suit because his injuries were "incident to military service."76 The Fifth Circuit vacated that decision on grounds that the district court should have dismissed the suit for lack of subject matter jurisdiction rather than grant summary judgment. On remand, Stanley amended his complaint to assert a constitutional claim against the government officers-a so-called Bivens claim-for denial of his constitutional right to be free to decide for hinself whether to become a test subject in drug experiment. ${ }^{77}$

In Bivens v. Six Unknown Named Agents of Federal Bureau of Narcotics, ${ }^{78}$ the Supreme Court estabhished that the victim of a constitutional

73. 'M. Lee \& B. Shlain, supra note 66 , at 40.

74. Stanley alleged negligence in the following respects:

(1) Defendants knew or should have known that LSD is a consciousness and behavior altering drug capable of producing irreparably harmful results, including death, and that the drug would affect different persons in different and unpredictable ways; (2) Defendants breached their duty to warn [Stanley]; (3) Defendants failed to take adequate precautions; (4) Defendants negligently failed to debrief Stanley after administering the drug to advise of the potentially hazardous physiologieal and psychological effects; (5) Defendants negligently failed to continue monitoring [Stanley] following the experiment; [and] (6) Defendants neghigently failed to obtain [Stanley's] informed consent.

Stanley v. CIA, 639 F.2d 1146, 1149 n.3 (5th Cir. 1981).

75. See supra notes $28-34$ and accompanying text.

76. 549 F. Supp. 327, 329 (S.D. Fla. 1982).

77. The Supreme Court has recognized that there is a constitutional right to be free to decide for oneself whether to submit to drug therapy. Mills v. Rogers, 457 U.S. 291, 298-302 (1982) (recognizing due process right of imvoluntarily committed inental patient to refuse treatment with antipsychotic drugs).

78. 403 U.S. 388 (1971). 
violation by a federal officer has the right to recover damages against the official in federal court despite the absence of any statute conferring such a right, unless one of two conditions is present: (1) The defendant demonstrates "special factors counselling [the court's] hesitation in the absence of affirmative action by Congress,"79 or (2) Congress has provided an equally effective remedy and declared explicitly that it is a substitute for recovery directly under the Constitution. ${ }^{80}$ The damages remedy stems from the Supreme Court's article III power to award damages, even against unconsenting federal officials, when necessary to vindicate constitutionally protected interests. Without this remedy, victims of constitutional torts would lack legal redress agamst federal officers violatimg their constitutional rights. ${ }^{81}$

Master Sergeant Stanley's Bivens claim asserted that the government deprived him of liberty without due process by denying him the right to be free to decide for himself whether to submit to drug experimentation. 82 The district court held:

The surreptitious administration of LSD to an unwitting servicennan who beheves he is involved in a project important to the development of defenses to chemical warfare constitutes a violation of the rights of privacy and bodily integrity, and of the right of an individual to control his mind, his private thoughts and his intellectual process. ${ }^{83}$

None of the judges involved at any stage of this complex hitigation, including Justice Scalia who wrote the Court's opimion disallowing Stanley's Bivens claim, disagreed that Stanley's injuries resulted from a violation of his constitutional rights.

The later stages of this higation turned on the Supreme Court's decision in Chappell v. Wallace, which denied Bivens relief for five black men entisted in the Navy who alleged racial discrimination by their superior officers in job assigninents and performance evaluations. ${ }^{84}$ Citing concerns for the "inescapable demands of military discipline," Court in Chappell rnled that "the need for unhesitating and decisive action by military officers and equally disciplined responses by enlisted personnel would be undermined by a judicially created remedy exposing

79. Id. at 396.

80. Id. at 397.

81. See generally Dellinger, Of Rights and Remedies: The Constitution as a Sword, 85 Harv. L. Rev. 1532, 1558 (1972); Lehmann, Bivens and Its Progeny: The Scope of a Constitutional Cause of Action for Torts Committed by Government Officials, 4 HASTINGS CONST. L.Q. 531, 597-603 (1977); Note, Rethinking Sovereign Immunity After Bivens, 57 N.Y.U. L. Rev. 597, 621-26 (1982). 82. Stanley v. United States, 549 F. Supp. 327, 330 (S.D. Fla. 1982), aff'd, 786 F.2d 1490 (11th Cir. 1986), rev'd, 483 U.S. 669 (1989); see also Mills v. Rogers, 457 U.S. 291 (1982).

83. Stanley, 549 F. Supp. at 331.

84. 462 U.S. 296,305 (1983).

85. Id. at 300 . 
officers to personal hability at the hands of those they are charged to command." 86 The Chappell Court rehed on the Feres doctrine to hold that "the unique disciplinary structure of the Military Establishment and Congress' activity in the field constitute 'special factors' which dictate that it would be inappropriate to provide enlisted military personnel a Bivens-type remedy against their superior officers." ${ }^{87}$ The defendants in Stanley moved to dismiss, asserting that the need to protect military discipline, as recognized in Chappell, precluded civil adjudication of Stanley's claims.

The district court in Stanley imterpreted Chappell to bar only actions "in which a member of the military brings a suit against a superior officer for wrongs which involve direct orders in the performance of military duty and the disciphine and order necessary thereto."88 Accordingly, the district court found the analogy between Stanley's claims and those asserted in Chappell unconvincing:

[Stanley]'s Bivens action in the instant case neither involves nor threatens to coinpromise military discipline. The case does not involve a combat or combat-training situation; it does not involve any exigent circumstances; and it is not a case in which Stanley was either ordered or obhgated to participate in a military exercise. ${ }^{89}$

[B]y donning a uniform, a inember of the Army does not volunteer himself to be duped and deceived into becoming a guinea pig for his superiors, and consequently to be deprived of his inost fundainental constitutional and human riglts. The "peculiar and special relationship of the soldier to his superiors" does not permit the violation of those fundainental rights in a situation that does not involve inilitary discipline and duty. ${ }^{90}$

The Eleventh Circuit agreed that, unike Chappell, the adjudication of Stanley's claims would not undermine the "special nature of military life, the need for unhesitatimg and decisive action by military officers and equally disciplined responses by enlisted personnel."91 Furthermore, Congress's plenary authority over the military did not militate against permitting Stanley's Bivens claim because "[t] hose intrainilitary administrative procedures which the Court found adequate to redress the servicemen's racial discrimination complaints in Chappell are clearly inadequate to compensate Stanley for the violations complained of

86. Id. at 304.

87. Id.

88. Stanley v. United States, 574 F. Supp. 474, 479 (S.D. Fla. 1983), affd in part, rev'd in part, 786 F.2d 1490 (11th Cir. 1986), rev'd in part, vacated in part, 483 U.S. 669 (1987).

89. Id. at 479.

90. Id. at 482 .

91. Stanley v. United States, 786 F.2d 1490, 1495 (11th Cir. 1986) (citing Chappell, 462 U.S. at 304), rev'd in part, vocated in part, 483 U.S. 669 (1987). 
here."92 Undaunted by the Eleventh Circuit's refusal to accept the purported precedent of Chappell for the claim brought by Master Sergeant Stanley, the Army appealed to the Supreme Court.

\section{B. The Supreme Court's Decision}

The issue before the Supreme Court was whether Stanley's allegations of surreptitious drugging, plus the government's failure to notify him or offer subsequent treatment, were claims which the court could not address because of "special factors counselling hesitation." That issue turned on whether Chappell's incident-to-service test was co-extensive with the Feres bar against suits brought under the FTCA. Stauley argued that the defendants were not his superior officers, indeed they may have been civilians, and therefore the chain-of-command concerns underlying Chappell were not implicated-his injuries simply were not incident to service. The success of that argument rested on the definition of the term "incident-to-service." The broader the definition, the less likely the conduct would be held justiciable.

In a five-to-four decision, the Supreme Court reversed Stanley's victory in the circuit court on grounds that the same "special factors" counselling restraint in Chappell applied to Stanley's action. ${ }^{93}$ Justice Scaha's majority opinion recognized that there are "varying levels of generahty at which one may apply 'special factors' analysis," 94 from allowing suits for egregious conduct even in the officer-subordinate context, to disallowing suits only if "it affirmatively appears that military discipline would be affected" or "disallow[mg] Bivens actions whenever the injury arises out of activity 'incident to service." "95 The choice depends "upon how harmful and inappropriate judicial intrusion upon military discipline is thought to be."96 As Justice Scalia concluded for the Court: "This is essentially a policy judginent ...."97

Justice Scaha, for the majority, based that policy judgment not on what happened to Master Sergeant Stanley or the need for accountability, but on the need to protect military concerns:

A test for liability that depends on the extent to which particular suits would call into question military discipline and decision-making would itself require judicial inquiry into, and lience intrusion upon, military matters. Whetler a case implicates those concerns would often be problematic, raising the prospect of compelled depositions and trial

92. Id. at 1496.

93. 483 U.S. 669,680 (1987).

94. Id. at 681 .

95. Id.

96. Id.

97. Id. 
testimony by military officers concerning the details of their military commands. Even putting aside the risk of erroneous judicial conclusions (which would becloud military decision-making), the inere process of arriving at correct conclusions would disrupt the military regime. The "incident to service" test, by contrast, provides a line that is relatively clear and that can be discerned with less extensive inquiry into military matters.

... The "special facto[r]" that "counsel[s] hesitation" is not the fact that Congress has chosen to afford some manner of relief in the particular case, but the fact that congressionally uninvited intrusion into military affairs by the judiciary is inappropriate. ${ }^{98}$

The issue of whether the injury was incident to service within the ineaning of Feres already had been decided adversely to Stanley: "The experiment was conducted on an Army base by and for the benefit of the Army. Thus, the relationship between Stanley and the allegedly neghgent individuals stemmed from their official inilitary relationship." 99 The point at issue was not whether Stanley had an adequate federal reinedy for his injuries nor the particular defendants' iminumity to such an action. The Court's holding was based simply on the conclusion that "no Bivens reinedy is available for injuries that 'arise out of or are in the course of activity incident to service." "100 Simply put, having found that the challenged drugging took place on an Army base pursuant to official orders, it followed necessarily that the conduct was protected. Accordingly, Stanley's claim was decided by the broad and unequivocal definition of "incident to service."

Justice O'Connor dissented on the grounds that Stanley's injuries were the result of conduct "so far beyond the bounds of human decency that as a inatter of law it simply cannot be considered a part of the military mission."101 Justice O'Connor did not dispute the principle that Chappell bars suits involving harm caused as a result of inilitary service; rather, she disagreed that the application of that bar could "insulate defendants froin hability for deliberate and calculated exposure of otherwise healthy inilitary personnel to inedical experimentation without their consent, outside of any combat, combat training, or inilitary exigency, and for no other reason than to gather information on the effect of lysergic acid dietliylamide on human beings." 102

Justice Brennan, joined in his dissent by Justices Marshall and Stevens, began with reference to the 1947 medical trials at Nüremberg which "deeply impressed upon the world that experimentation with un-

98. Id. at 682-83.

99. 639 F.2d 1146, 1152 (1981).

100. 483 U.S. at 684.

101. Id. at 709 .

102. Id. 
knowing human subjects is morally and legally unacceptable."103 Accordingly, the first principle of the Nüremburg Code is that the voluntary consent of human subjects is essential prior to experimentation. In defiance of this principle, Justice Brennan pointed out, the military drugged "unwitting, nonvolunteer" 104 Americans. When these activities were discovered, the military maintained that it should "remain free to violate the constitutional rights of soldiers without fear of money damages."105 Replied Justice Brennan: "[G]overnment officials (military or civilian) must not be left with such freedorn. ... Serious violations of the constitutional rights of soldiers, must be exposed and pumished."106

According to Justice Brennan's dissent, the majority opmion conferred absolute immumity on the defendant officials despite longstanding precedents establishing liability for intentional violations of constitutional rights. ${ }^{107}$ More to the point, in applying Chappell, the majority ignored the fact that the defendants were not Stanley's superior officers and that the concern for soldiers' unquestioned obedience to orders is not implicated in cases in which a soldier sues civilian officials. ${ }^{108}$ The CIA, after all, did not command hin to undergo the experiments nor could it have so ordered a soldier. The CIA is not a branch of the United States military and has no direct authority over Army personnel. ${ }^{109}$ Justice Brennan observed:

The Court fears that military affairs might be disrupted by factual inquiries necessitated by Bivens actions. The judiciary is already involved, however, in cases that implicate military judgments and decisions .... Unless the command relationship . . . is involved, these violations should receive moral condemnation and legal redress without limitation to that accorded neghigent acts. ${ }^{110}$

103. Id. at 687.

104. Id. at 688 (quoting S. REP. No. 755, 94th Cong., 2nd Sess., Pt. 1, at 385 (1976)).

105. Id. at 689 .

106. Id. at $689-90$.

107. Id. at 691-99. Justice Scalia answered this contention as follows: "[T] $]$ he availability of a damages action under the Constitution for particular injuries (those incurred in the course of military service) is a question logically distinct from inmunity to such an action on the part of particular defendants." Id. at 684 .

108. Id. at 703 n.26. Even the need for instinctive obedience is not absolute. Justice Brennan cited United States v. Calley, 22 C.M.A. 534, 48 C.M.R. 19 (1973), and United States v. Kinder, 14 C.M.R. 742 (A.F.C.M.R. 1953), as support for the proposition that obedience to orders is no defense to charges of having coinunitted criminal acts. 483 U.S. at 703.

109. See Major v. United States, 835 F.2d 641, 645 (6th Cir. 1987) (characterization of coininand decisions).

110. 483 U.S. at 703-04. Justice Brennan's point is an inportant reninder of Judge Wilkey's argunient in the Raminez de Arellano decision, discussed above, that legal review of military decision is not uncommon. See also, Kellman, De Coupling The Military Industrial Complex-The Liability of Weapons Makers For Injuries to Servicemen, 35 CLEV. ST. L. REV. 351, 397-401 (1987). 
Most important to Justice Brennan was that Chappell was a narrow exception to the significant interests protected by Bivens actions:

Were I to concede that military discipline is somehow implicated by the award of damages for intentional torts against civilian officials, I would nonetheless conclude, in accord with our usual immunity analysis, that the decision-making of federal officials deliberately choosing to violate the constitutional rights of soldiers should be impaired. I cannot comprehend a policy judgment that frees all federal officials froin any doubt that they may intentionally, and in bad faith violate the constitutional rights of those serving in the Armed Forces.

... Soldiers ought not be asked to defend a Constitution indifferent to their essential human dignity. ${ }^{111}$

\section{The Purpose of Deference to Military Discretion-Part I}

What is the military security justification for testing LSD on soldiers? LSD testing was never an important part of the strategic debate nor has it been defended explicitly by the military establishment. The majority of the Supreme Court im Stanley refused to hear a constitutional challenge to nonconsensual drugging on the grounds that judicial review would intrude into military affairs. The Supreme Court required neither evidence that LSD testing bore a significant relationship to inilitary security nor proof of a chain of authority from those who administered the tests to those at the "planning level" where policy is decided. Moreover, none of the criteria of nonjusticiability were employed. According to the Court, the only relevant consideration was that the challenged conduct was "incident to service;" any further judicial inquiry was necessarily intrusive.

The Supreine Court simply refused to allow a legal challenge to a military matter because of its concern with inaintaining the institutional division between the judiciary and the military. In theory, the governinent's surreptitious experimentation on Master Sergeant Stanley could have involved any substance: steroids, opiates, chemical weapons, or even radioactive inaterials. Not a word in Justice Scalia's opinion suggests that there is any limit on what type of testing military authorities can do to soldiers. As long as the testing takes place on a military base, involves military personnel, and is performed under proper inilitary coinmand, the Court will not allow the Constitution to intrude on the discretion of military authorities. ${ }^{112}$

111. 483 U.S. at $706-08$.

112. An interesting test might involve the impact on the fighting capability of personnel injected with any of a variety of biotoxins. Not only would a test increase the scientific community's under- 
This conclusion is indeed ominous. Heretofore, the judiciary abstained from reviewing matters that implicated the hierarchy of cominand and the need for immediate obedience to orders. These two conditions underlie Chappell, the precedent for Justice Scaha's opimion. By focusing on the officer-subordinate relationship, deference under the doctrine of "special factors counselling hesitation" inade sense. But Master Sergeant Stanley's claims did not involve such a relationship. Instead of protecting military cominands from subsequent review, the Court shrouded the government's determination that LSD testing was important to military security. Review of that determination has far different innplications than a review of officer-subordinate inatters. At issue here is not the need to ensure immediate obedience to authority-Master Sergeant Stanley was not alleging improper conduct by a senior officer. He was alleging that a military prograin had violated his rights. The trial of this clainı would have inquired into important inatters of administrative process: What was the statutory or executive authority for the program? Did those who inade the decision to proceed with the program have sufficient delegated authority? Did the execution of the progrant at the operational level reasonably comply with decisions made at the planning level? For the first time in American law, the inajority of the Supreine Court decided that the courts inay not even address these questions to the military.

The military should have the imitial burden to establish more than the mere fact that the conduct took place on a military base; it should be obligated to advance a reasonably authoritative colmection between the testing and a policy decision by legitimate congressional or Executive authority. The denionstration of a clear authoritative structure froin the administrator of the test up to a senior Executive Branch official would have exposed the level of initiative for the program. The possibility exists that drugging soldiers was a rogue program of which the nation's leaders were unaware: The LSD testing inay have resulted from the caprice of soineone low in the chain of cominand who ordered this program of covert drugging for purposes scarcely related to national interests. It is unclear whether proper congressional or Executive authority to drug Stanley existed; Justice Scaha's opimion conspicuously fails to cite any evidence of such chain-of-command authority. ${ }^{113}$

standing of metabolic reaction to such substances, but testing also would protect against the "surprise" factor if such substances were used on military personnel.

113. A contrary position was taken in Orlivow v. United States, 682 F. Supp. 77, 81 (D.D.C. 1988): "When a decision is made to conduct intelligence operations by methods which are unconstitutional or egregious, it is lacking in statutory or regulatory authority." 
Even if a reasonable authority structure is asserted, why should the military not be required to undertake properly conducted research studies if it wants to learn of the effects of dangerous drugs? The military should realize that there are proper (and hence improper) methods of accomplishing certain ends. It would not be unusual for a biomedical laboratory to test drugs pursuant to a military contract; private institutions inust follow professional standards and procedures. In the context of LSD testing, why did the authorities decide to administer the tests through non-medical personnel? Why were soine subjects, including Stanley, coinpletely uninformed about the substance of the test?

All these questions could be answered without jeopardizing military security: if reasonably answered, there might be a basis for mvoking the discretionary function exception. But by relying on the "special factors counselling hesitation" exception to the Bivens doctrine, the military defendants in Stanley convinced the Supreme Court to render the controversy nonjusticiable. ${ }^{114}$ Without judicial review, it is impossible to know exactly why these tests were undertaken or low they were administered. Without compelling evidence of an apparent military security justification nor an authoritative structure linking the tests' execution to senior political officials, the hability exception for conduct "incident to service" was given nearly limitless application. As Justice Murphy warned in Korematsu, the claim of military security leaves important legal issues entirely unaddressed. ${ }^{115}$

Perliaps most chilling is that Justice Scahia's opinion evinces no dismay (or repugnance) about what the Army did to Master Sergeant Stanley. Nowliere does the opimion even faintly suggest that Master Sergeant Stanley was caused unreasonable harm. Justice Scalia's denial of the central reality of the case suggests a tolerance for conduct-inedical experimentation on non-volunteer humans-that the Nüremburg Trials condeinned as unjustifiable on a claim of "Inilitary necessity." Yet the Supreme Court of the United States held that such conduct was nonjusticiable because it was "incident to service,"116 - to award legal redress wonld "require judicial inquiry into, and lience intrusion upon, military matters."117

The obvious reply to this holding is to agree that judicial review and a civil suit to redress injuries would be intrusive. The relevant question,

114. Justice Scalia's rejection of arguments regarding immunity in favor of arguments regarding the need to protect the military from intrusion confirms that the Court's holding is analogous to a determination of nonjusticiability.

115. Korematsu v. United States, 323 U.S. 214, 234 (1944) (Murphy, J., dissenting).

116. Umited States v. Stanley, 483 U.S. 669, 684 (1987).

117. Id. at 682 . 
however, is whether that intrusion would be constitutional. The Supreme Court answered this question negatively, despite the commitment of the Western world at Nüremberg to safeguard humans from non-voluntary testing. The hands of those responsible for the testing have been washed clean.

\section{The Atomic Testing Litigation}

The litigation mvolving claims of mjuries resulting from atomic testing ${ }^{118}$ differs from the Stanley hitigation in three significant respects. First, atomic weapons testimg was, by any conceivable measure, far more essential to national security than was LSD testing. It hardly can be disputed that any potential foe was cautioned more by the U.S. military's demonstration of nuclear weaponry than by the military's testing of hallucinogemic drngs. Second, although the consequences of atomic testing were far more widespread and more severe than the consequences of LSD testing, the causal connection between the testing and the resulting injuries was more ambiguous im the context of atomic testing. For purposes of tort accountability, the fact that atomic testing may have caused innumerable cancers is both more serious and less definite than Master Sergeant Stanley's probleins. Third, the atomic testing hitigation never raised constitutional questions for the Supreme Court to address; consequently, the appellate court decision examined here, Allen v. United States, ${ }^{119}$ sends a more ambiguous sigual about the scope of review of military discretion than does the Supreme Court's opmion im Stanley. The following discussion does not attempt to reargue the strategic merits of atomic testing; instead, this discussion examines the claims the plaintiffs made at trial and their legal resolution in the court of appeals.

\section{A. The Prima Facie Case}

Hundreds of atomic bomb blasts symbolized the Cold War until the Partial Test Ban Treaty of 1963 prohibited above-ground explosions. According to the trial court's findings in Allen, these blasts exposed over one million people to radioactive fallout, including more than 200,000 military personnel. Many scientists now beheve that radiation exposure during weapons testing caused thousands of cancers, including leukemia, prostate cancer, maliguant blood disease, bone marrow cancer, and ma-

118. Although most of the test cxplosions at issue in the litigation involved thermonuclear (hydrogen/fusion) bombs rather than atomic (uranium/fission) bombs, the term "atomic testing" is used throughout this discussion for purposes of consistency.

119. 816 F.2d 1417 (10th Cir. 1987), cert. denied, 484 U.S. 1004 (1988). 
lignant lyinplioma, as well as otlier maladies including diabetes. ${ }^{120}$ Some victims-private citizens downwind of the explosions and military personnel engaged im maneuvers at or near the test site-filed claims against both thic government and the private contractors imvolved in conducting the tests.

In late 1979, the first claims were filed with the U.S. Department of Energy, assertimg damages of over a liundred million dollars and charging negligent conduct that led to the injury and death of persons exposed to radiation from the test site. ${ }^{121}$ When the Department of Energy did not act on these claims, the victims souglit judicial relief. ${ }^{122}$ By 1986, there were more than fifty separate lawsuits representing over 3000 plaintiffs who sought im excess of $\$ 8.5$ billion in claims arising from the atomic weapons testing program. ${ }^{123}$

Atomic testing has been and continues to be extremely controversial. Every President from Truman to Bush lias regarded testing as critical to national security because of the threat posed by the Soviet Union. Presidents Truman, Eisenhower, and Kennedy expressly supported above-ground atomic testing prior to the 1963 treaty prohibiting such tests. The tests' objectives included: (1) enhancement of weapons development by establishing the operability and reliability of various configurations and sizes of warheads, their effects and new applications; ${ }^{124}$ (2) advancement of nuclear technology to reduce collateral damage by increasing the explosive efficiency of warlieads; ${ }^{125}$ (3) support for the scientific researcli efforts of the nuclear weapons laboratories by providing real

120. Factual assertions unaccompanied by citation are either matters of common knowledge or involve facts found by the trial court in Allen, 588 F. Supp. 247 (D. Utah 1984), that were not controverted on appeal.

121. Claims also were filed by veterans with the Veterans' Administration. The processing of the clains has been facilitated by the Veterans' Dioxin and Radiation Exposure Compensation Standards Act, Pub. L. No. 98-542, 98 Stat. 2725 (1984).

122. See Note, Atomic Veterans' Tort Claims: The Search for a Tort Remedy Dead Ends with the Veterans Administration, 61 NOTRE DAME L. REV. 819 (1986). Veterans' claiıns generally have been unsuccessful in obtaining judicial relief. See, e.g., Gaspard v. United States, 713 F.2d 1097 (5th Cir. 1983).

123. Schneider, Opening the Record on Nuclear Risks, N.Y. Times, Dec. 3, 1989, at E6, col. 1.

124. See Mark, The Purpose of Nuclear Test Explosions, in J. Goldblat \& D. Cox, Nuclear Weapon Tests: Prohibition or Limitation? 32, 34 (1988):

[T] he starting conditions for thermonuclear burning in a device whose behaviour depends essentially completely on the progress of that burning cannot be simulated in the laboratory, but are only realized in the course of a nuclear test. ... If the actual behaviour departed from that calculated, it might be possible to draw conclusions as to the reason. Such observations could then suggest corrective changes to be incorporated in sonie subsequent nuclear test.

125. Review of Arms Control and Disarmament Activities: Hearings before the Special Panel on Arms Control and Disarmament of the Procurement and Military Nuclear Systems Subcommittee of the House Committee on Armed Services 99th Cong. 1st Sess. 134-49 (1985) (statement of Dr. C. Paul Robinson, Principal Assoc. Dir. for Nat'1 Sec. Prograins, Los Alamos Nat'1 Laboratory). 
data on the effects of nuclear explosions; ${ }^{126}$ (4) improved assessment of target vulnerability to determine how to protect military facilities and troops from the effects of detonations and improving radiological safety; ${ }^{127}$ (5) maimtenance of confidence in the reliability of deployed weaponry; ${ }^{128}$ and (6) increased comprehension of the weapons programs of other nations. ${ }^{129}$ "A particular objective of the tests," according to one court, "was to determine the effects of nuclear explosions on the equipment, clothing, weapons and fighting capability of military personnel." 130

Many experts beheve that these objectives could have been achieved without nuclear testing, and many beheve that the achievement of these objectives did not warrant the environmental damage caused by the tests. ${ }^{131}$ Yet the debate over the contribution of nuclear weapons testing to the deterrence posture of the United States has not been debated fiercely in the courts. This is as it should be: The judiciary lacks the constitutional authority to decide the merits of nuclear testing as it relates to military strategy. None of the hitigants who sought tort recovery for injuries caused by nuclear weapons testing ever seriously asserted that the courts could or should decide this critical issue of defense policy. They sinply based their claims on the alleged gross negligence of those persons who carried out the weapons testing.

Congressional hearings in 1979 revealed that the government had conducted above-ground atomic testing with hittle regard for minimizing the exposure risk of either military personnel or down-range civilians. Indeed Congress's report, "The Forgotten Guinea Pigs," sharply condemned the federal government for failing to give adequate warning of the dangers of fallout, inaccurately estimating radiation exposure, and knowingly falsifying measurements of radiation exposure. ${ }^{132}$ These hear-

126. Id. at 197-214, (statement of Roy Woodruff, Assoc. Dir. for Defense Systems, Lawrence Livermore National Laboratory).

127. Id. at 75-81 (statement of Hon. Richard L. Wagner, Assistant to the Secretary of Defense for Atomic Energy).

128. See Mark, supra note 124 , at $38-41$.

129. See IV. Van Cleave \& S. Cohen, Nuclear Weapons, Pollcies, and the Test Ban IsSUE ch. 5 (1987).

130. In re Consolidated United States Atmospheric Testing Litig., 616 F. Supp. 759, 763 (N.D. Cal. 1985), cert. denied, 485 U.S. 905 (1988). See generally A. TrTUS, BomBS IN THE BACKYARD: Atomic Testing AND AMERICAN Politics (1986) (documentimg the history of the atomic bomb, with great emphasis on the obvious and consistent efforts of AEC to generate domestic public support for the U.S. atomic weapons testing and development programs).

131. See generally, R. Divine, Blowing on the Wind, The Nuclear Test Ban Debate, 1954-60 (1978) (an in-depth discussion of various experts' positions on the proposed nuclear test ban of the 1950s and 1960s).

132. STAFF OF HOUSE SUbCOMM. ON OVERSight AND INVESTIGATIONS, COMM. ON INTERState AND Foreign COMmerce, "The Forgotten Guinea Pigs": A Report on Health 
ings confirmed the scientific community's fears that atmospheric nuclear testing poses pathological and genetic dangers. Scientists in the late 1950s had predicted that exposure to radioactive fallout from nuclear weapons testing would cause thousands of deaths and injuries. ${ }^{133} \mathrm{Re}-$ cently revealed evidence suggests that military authorities knew as early as 1946 that there was a significant link between radioactive fallout and cancer, and that the Atomic Energy Commission (AEC) deliberately chose not to share that knowledge or protect affected persons. ${ }^{134}$

It is important to understand the procedural developinent of the litigation over the claims for dainages from atomic tests. The clains of nearly 1200 individuals (residents of Utah, Nevada, and Arizona) were heard by the Utah District Court in Allen v. United States. ${ }^{135}$ The plaintiffs' arguments focused on the government's alleged failure to (1) monitor off-site fallout exposure, and (2) provide needed public information on radioactive fallout. The trial court in Allen selected twenty-four "bellweather clamis,"136 and made the following findings about culpable government decisions that would support liability for injury under standard tort analysis: the decision to monitor randomly rather than on a comprehensive, person-specific basis; decisions not to use thyroid or whole body counters; decisions regarding the limited use of urine, fecal, and blood sampling; the decision not to test milk samples in order to avoid arousing public concern; decisions to forego internal fallout assessment froin inhalation of fallout particles; decisions regarding the extent of follow-up montoring in downwind communities; the decision to distribute film badges and pocket dosimeters to a select number of residents rather than to every resident; the decision regarding the duration of monitoring; decisions respecting the number of personnel and amount of equipment committed to the monitoring program; and decisions concerning the content and appropriate tone of the information given the public,

EFFECTS OF LOW-LEVEL RADIATION SUSTAINED AS A RESULT OF THE NUCLEAR WEAPONS TESTing Program Conducted by the United STates Government, Doc. H.R. No. 382, 96TH CONG., 2D SESS. 37 (Comm. print 1980).

133. R. Miller, Under the Cloud: The Decades of Nuclear Testing 304 (1986). Not all scientists agreed. See Teller, The Compelling Need for Nuclear Tests, LIFE, Feb. 10, 1958, at 64 66.

134. Clearance of Discussion on Product Contamination After Underwater Bomb Detonation During Part of Informal Talks at Bikini (Oct. 9, 1946), filed in Memorandum in Support of Defendant's Motion for Summary Judgment, Broundy v. United States, No. 79-2626-LEW (C.D. Cal. Nov. $12,1985)$.

135. 588 F. Supp. 247 (D. Utah 1984), rev'd, 816 F.2d 1417 (10th Cir. 1987), cert. denied, 484 U.S. 1004 (1988).

136. This group of plaintiffs consisted of twelve males and twelve females, four of whom were youngsters who had died in early adolescence. Nineteen were dead by the time of trial, eight of leukemia, one of Hodgkin's disease, a lymphoma, and the rest of cancers of vital organs. See generally P. FRADKIN, Fallout-AN AMERICAN NUCLEAR TRAGEdY 165-81 (1988). 
as well as the use of pamphlets and films as education media. ${ }^{137}$ Accordingly, the court entered judgment against the government on the claims of mine plaintiffs, ${ }^{138}$ with damages in excess of $\$ 2.6$ million. ${ }^{139}$ Recently, however, the Tenth Circuit in Allen v. United States ${ }^{140}$ reversed the district court and held that the civilian claims are non-litigable. ${ }^{141}$

Nearly simultaneously, a California district court in In Re Consolidated Atmospheric Testing Litigation ${ }^{142}$ tried forty-three consolidated actions of members of the military. Besides mvolving a different class of plaintiffs (servicemen rather than civilians), the California litigation urriquely involved claims agamst civihan contractors as well as the United States. The claims brought agamst the contractors confronted the Warner Amendment, ${ }^{143}$ which effectively immunizes federal contractors from such claims. Despite plaimtiffs' arguments that the Warner Amendment contravened the fifth amendinent and violated constitutional separation of powers, the district court substituted the Umited States for the contractors and dismissed the actions agamst those contractors. ${ }^{144}$ The district court went on to disimiss the claims against the government ${ }^{145}$ citing, inter alia, the FTCA discretionary function exception. ${ }^{146}$ The Ninth Circuit in In Re Consolidated Atomic Testing Litiga-

137. Allen, 588 F. Supp. at 374-404.

138. Id. As to the remaining plaintiffs, Judge Jenkins found an absence of evidence establishing causation of injury. $I d$. at 433.

139. Id. at 447 .

140. 816 F.2d 1417 (10th Cir. 1987).

141. Id. at 1424.

142. 616 F. Supp. 759 (N.D. Cal. 1985), affd 820 F.2d 982 (9th Cir. 1987), cert. denied, 485 U.S. 905 (1988).

143. 42 U.S.C. $\S 2212$ codified $\S 1631$ of the Departınent of Energy National Security and Military Applications of Nuclear Energy Authorization Act of 1985, Pub. L. No. 98-525, 98 Stat. 2646 (1984). It provides that an action against the United States under the Tort Clains Act is the exclusive remedy for clains of injuries "due to exposure to radiation based on acts or onissions by a contractor in carrying out an atomic weapons testing prograin under a contract with the United States." 42 U.S.C. $\$ 2212(a)(1)$ (Supp. V 1987). Additionally, it requires that any action against these contractors be inaintained solely against the United States pursuant to the FTCA. Id. $\S 2212(a)(2)$.

144. In re Consolidated U.S. Atnospheric Testing Litig., 616 F. Supp. at 771.

145. Id. at 780 .

146. The district court stressed that the need to balance risks against test objectives was particularly a policy function of the type traditionally accorded discretion:

The responsibility for carrying out the Safety Plan was assigned to the officials in cliarge of the tests who had discretion to adopt and inodify the Plan as necessary to achieve the objectives of the test. A court would be ill-equipped to evaluate the judgments concerning safety made by those officials based on the exigencies of the inoinent. Any attempt to do so would, moreover, require a comprehensive re-examination of the conduct of the tests and the decisions inade during their course which would itself defeat the purpose of the exception. The consequences of such a re-examination would be to hamper the governinent in its future conduct of weapons tests and similar operations affectiug the national security. Id. at 774 . 
tion, ${ }^{147}$ affirmed the district court's demal of the injured servicemen's right of recovery by upholding the constitutionality of the Warner Amendment and grounding the government's immunity solely on the basis of the discretionary function exception. ${ }^{148}$

The result of the Tenth and the Ninth Circuits' decisions in Allen and Consolidated Atomic Testing, respectively, is that those responsible for the consequences of atomic testing are immune from legal accountability for their conduct.

\section{B. The Tenth Circuit's Holding In Allen v. United States}

The Tenth Circuit panel stressed that the Operation Plan for each test, including the Atomic Energy Commission-established radiation exposure limits, had been approved by the AEC, the National Security Council, and finally by the President. The court held, "each test explosion was executed according to detailed plans which the AEC officially reviewed and adopted." 149 Various military and civilian committees as well as medical and scientific experts took part in making the decisions that the AEC incorporated into the Operation Plan. ${ }^{150}$ Designated units in each test organization were assigned responsibility for radiological safety. ${ }^{151}$

Plaintiffs' claims, which the court characterized as distinguishing between "the discretionary initiation of government programs, at the highest levels of administration, and the decisions involved im carrying out programs, at lower levels," ${ }^{152}$ fell withm the immunity announced by

147. 820 F.2d 982 (9th Cir. 1987), cert. denied, 485 U.S. 905 (1988). It should be noted that Judge Anderson's opinion for the Ninth Circuit panel is, with minor exceptions, simply a lengthy quotation from the district court's opinion. The only important difference was the Ninth Circuit did not reach the bases for dismissing the actions against the government other than the discretionary function exception. It is unfortunate that on a matter of this significance, the Ninth Circuit panel did not feel compelled to write its own opinion.

148. Id. at 984-85. The Ninth Circuit's decision reflected deference to the authority of the Atomic Energy Commission over the tests:

[The AEC had explicit authority] to operate a "program of federally conducted research and development with the paramount objective of assuring the common defense and security." To this end the AEC was authorized to conduct experiments, undertake research, and develop the military applications of atomic energy either in its own facilities or pursuant to arrangements with public or private institutions. ... The AEC thus established a program of pervasive ' $[\mathrm{g}]$ overnmental control over the production, ownership, and use of fissionable material' including the development and testing of nuclear weapons.

Id.

149. Allen v. United States, 816 F.2d 1417, 1419 (10th Cir. 1987), cert. denied, 484 U.S. 1004 (1988).

150. Id. at 1423-24.

151. Id. For a thorough discussion of the AEC procedure followed for each test in the context of the atomic bomb's test organization structure, see H. BALL, JUSTICE DOWNWIND-AMERICAN Atomic Testing Program in the 1950s, at 33-34 (1986).

152. Allen, 816 F.2d at 1420 . 
the Supreme Court in United States v. S.A. Empresa de Viacao Aerea Rio Grandense (Varig Airlines). ${ }^{153}$ In Varig Airlines, victims of two airplane accidents challenged "low-level" Federal Aviation Administration (FAA) approval of defective and flammable materials used to construct the planes. The Supreme Court lield that the FAA's allegedly negligent decisions implementing plane inspection and design certification programs constituted discretionary functions, and thus were immune from suit: "Where there is room for policy judgment and decision there is discretion. It necessarily follows that acts of subordmates in carrying out the operations of government in accordance with official directions cannot be actionable." 154

The Court in Varig Airlines ruled that the scope of the discretionary function exception covers more than the imitiation of programs; its application turns on the nature of the conduct ratlier tlian the status of the government official. The nature of the conduct was regulatory in that it involved the FAA's determination that a program of spot-checking manufacturers' comphance with minimum safety standards best accommodates the goal of air transportation in light of finite agency resources. Accordingly, the Court reversed the Nintll Circuit's judgment for plaintiffs because

[j]udicial intervention in such decisionmaking through private tort suits would require the courts to "second-guess" the political, social, and economic judgments of an agency exercising its regulatory function. It was precisely this sort of judicial intervention in policymaking that the discretionary function was designed to prevent. 155

In applying Varig Airlines to the facts in Allen, tlie Tenth Circuit held that the statutory duty to promote safety in connection with the atomic tests was broad and discretionary: "[I]t was left to the AEC, as in Varig it was left to the Secretary of Transportation and the FAA, to decide exactly how to protect public safety.... We cannot say that what was protected by the Supreme Court in Varig is now subject to liability." 156 Supporting this holding was the absence of evidence that tlose implementing the tests had violated the AEC's policy directives:

Neither the plaintiffs nor the district court have been able to point to a single instance in which test site personnel ignored or failed to implement specific procedures mandated by the AEC . . . .

153. 467 U.S. 797 (1984). Varig was decided after the district court verdict in Allen awarded judgment to nine plaintiffs but before the Tenth Circuit's decision.

154. Varig Airlines, 467 U.S. at 811 (quoting Dalehite v. United States, 346 U.S. 15, 35-36 (1953)).

155. Id. at 820 .

156. Allen, 816 F.2d at 1421 . 
Government hability cannot logically be predicated on the failure of test-site personnel to go beyond what the operational plans specifically required them to do ....

It is irrelevant to the discretion issue whether the AEC or its employees were neghigent in failing to adequately protect the public. ${ }^{157}$

Plaintiffs, however, sought to distinguish Varig Airlines by arguing that the challenge to those FAA decisions involved the actions of an agency supervising private individuals. Such regulatory discretion, the Varig Airlines Court observed, was at the core of what the discretionary function was intended to protect. ${ }^{158}$ But the Tenth Circuit found that Varig Airlines had expressly reaffirmed the earlier decision of Dalehite $v$. United States, ${ }^{159}$ and relied on Dalehite to dismiss the plaintiffs' claims in Allen.

In Dalehite, plaintiffs had sustained injuries from the explosion of two shiploads of ammonium mitrate fertilizer shipped by the War Department pursuant to a program to feed the populations of Korea, Germany, and Japan. Plaintiffs challenged the government's failure to investigate fully the hazards of the dangerous inaterial and its failure to warn adequately the nearby populace. The Supreme Court found that each link in the chain of decisions-from the cabinet-level decision to export the fertilizer, to the specific decisions to bag the fertilizer at a certain temperature-was discretionary and thus was entitled to iminumity. The Tenth Circuit in Allen found a close analogy to the Supreine Court's holding in Dalehite: "As with the AEC bomb tests, the production of fertilizer in Dalehite mvolved a mix of private and public facilities and employees. As with the AEC bomb tests, all plans for manufacturmg, packing, and shipping of the fertilizer in Dalehite were officially approved."160 Accordingly, the test for whether activity was "discretionary" turned on whether those who approved it were government officials. Other considerations that could serve to narrow the inmumity - whether those officials were passively accepting the decisions of private contractors, or whether those official decisions were in fact of a pohicy nature-were deleted from the analysis.

Judge Logan's majority opimion in Allen unabashedly adhered to this principle of broad sovereign immunity, stating that judicial reluc-

157. Id.

158. See Varig Airline, 467 U.S. at 819-20. See also Merklin v. United States, 788 F.2d 172, 174 (3rd Cir. 1986) (New Jersey "good Samaritan" rule does not apply to AEC "because theory attempts to hold AEC liable in its capacity as a regulator," the discretionary function exception will not permit this); Begay v. United States, 768 F.2d 1059, 1064 (9th Cir. 1985) ("non-regulatory acts ... fall within the framework of the [discretionary function] cxception"), cert. denied, 485 U.S. 935 (1988).

159. 346 U.S. 15 (1953).

160. Allen, 816 F.2d at 1423. 
tance to recognize that principle explained "much of the tangle of the prior FTCA cases."161 Of paramount importance was that the courts must not second-guess the judgments of an agency. The opinion's concluding paragraph speaks volumes:

The bomb-testing decisions made by the President, the AEC, and all those to whom they were authorized to delegate authority in the 1950s and 1960s, were among the most significant and controversial choices made during that period. The government deliberations prior to these decisions expressly balanced public safety agamst what was felt to be a national necessity, in hight of national and international security. However erroneous or misguided these detiberations may seem today, it is not the place of the judicial branch to now question thein. ${ }^{162}$

This terse disimssal leaves hittle room for negotiation: Because government officials determined that national security required atomic testing, the loss lies where it fell.

In a concurring opinion, Judge McKay took a somewhat more reflective position. The issue for Judge McKay was whether the evidence demonstrated negligent impleinentation of the government's discretionary decisions-in which case Varig Airlines would not bar review-as distinguished from operational level conformity to a discretionary plan that itself created an unreasonable risk of harm. Clearly troubled by the documented evidence of the horrific consequences caused by atomic testing, Judge McKay nevertheless was compelled to agree that plaintiffs lacked legal redress because "the discretionary function exception swallows the negligent decisions before us."163 Judge McKay concluded:

The broad safety language of the Atomic Energy Acts had to be translated into concrete plans, and that translation involved the very essence of social, economic, and political decision inaking - the precise policy choices protected by the discretionary function exception. These decisions concerned choices involving the social psychology of how best to inform without alarming residents, the most cost-effective way of using public funds to momitor fallout levels, and how best to use a finite number of personnel. In short, they required the AEC to establish priorities for the accoinplishment of its policy objectives by balancmg the objectives sought to be obtaimed against such practical considerations as staffing and funding. While those choices deviated from the standards against which liability is measured (where liability is available), Congress' determination to retain government immunity for discretionary functions puts those choices beyond our ability to review and puts compensation for mjury to individuals stemining from those choices beyond our power to order. Only Congress has the constitutional power to decide whether all costs of government activity

161. Id. at 1424.

162. Id.

163. Id. at 1426. 
will be borne by all the beneficiaries or will continue to be unfairly apportioned as in this case. ${ }^{164}$

\section{The Purpose of Deference to Military Discretion-Part II}

The legal dispute surrounding above-ground atomic testing is now over. There will be no trial to review what happened and what injuries the testing caused. The victims are without an opportunity for legal determination of whether the government's objectives could have been accomplished with less danger, or even whether those objectives should have been pursued. This result is deeply troubling. Never before or since in the history of the Republic has the government in time of peace caused so much misery. In the name of protecting the nation froin the Soviet threat, the government exploded nuclear weapons, and many citizens and soldiers are suffering as a result. That the United States government is immune from hability for its conduct reflects sadly on the judiciary's role in protecting our most fundamental right: the right to be secure from death and disease inflicted by those who rule us.

The problem with the Tenth Circuit's decision in Allen v. United States is not the discretionary nature of the decision to pursue atomic testing. After all, what could be more a matter of national security policy than the testing of nuclear weapons to arin the U.S. arsenal? Furthermore, an authoritative structure with clear lines of authority extended from the President through the AEC to the on-site officials who made the decisions. The real problem is that nowhere did the appellate court face the unprecedented magnitude of discretion afforded to those governinent officials who conducted the atonic tests. The discretionary function exception is inherently undefined, but this lack of definition should not mean that it is without limit. In Allen, the court invoked the exception to foreclose legal accountability precisely for those official actions that had the most serious consequences.

Indeed, the Allen court's glib analogy to Dalehite suggests a fundamental abdication of judicial responsibilities. While it is true that both cases involved tort claims stemming from explosions, it should not be beyond judicial notice that two shiploads of fertilizer create explosions of a different magnitude than hundreds of nuclear boinbs. A reasonable rule of law would attempt to balance the breadth of discretion with the magnitude of risk. In light of the enormous risks to distant populations and the ramifications for generations yet unborn, the "discretion" of atomic test officials should be less than that of officials supervising the slipment of fertilizer. Despite the enormous risks of atomic testing, the 
Tenth Circuit broadened the government's discretionary immunity simply because the testing was performed in the interests of national security.

Equally troubling is the fact that the issues in Allen were addressed incoinpletely and, consequently, the criteria of judicial deference to military discretion evolving from this decision is highly ambiguous. The appellate decision advanced only general criteria by which to demarcate the himits of the exception. Comments like "[w] here there is room for policy judgment and decision there is discretion," do not clarify the limits of discretion. An alternative approach employed by District Court Judge Schwarzer, in a related case involving claims by servicemen, ${ }^{165}$ cited three criteria to determine whether to apply the discretionary function exception: "(1) whether the decision was made at the planning level or the operational level, (2) whether the judiciary is in a position to evaluate the act or omission, and (3) whether judicial evaluation would impair the effective administration of government." 166 These criteria reflect a reasonable consensus of opmion regarding the appropriate use of the discretionary function exception; they are clearly consistent with the principles asserted in Part I. The problematic aspect of Allen is the non-application (or mis-application) of these criteria.

The court could have usefully apphied the plaminig level/operational level criterion which suggests that underlying concerns about sovereign immunity are more cogent when the President or a semior cabinet official makes a policy decision than when lower-level government employees decide how to implement plans. This distinction would require knowledge of whether each atomic test in fact was executed strictly in comphance with a comprehensive safety plan. If so, then it should follow that those officials who prepared the safety plan-senior officials at "the planning level"- shonld be immune from FTCA hability under the discretionary functions exception. However, plamtiffs in the atomic testmg litigation sought to show that the safety plans were inadequate and that the tests were not strictly in compliance with reasonable standards of care, clanning that responsibility for the discrepancies was at the operational level. ${ }^{167}$ The Tenth Circuit, however, refused to inquire whether

165. In re Consolidated U.S. Atmospleric Testing Litig., 616 F. Supp. 759 (N.D. Cal. 1985), aff'd, 820 F.2d 982 (1987), cert. denied, 485 U.S. 905 (1988).

166. Id. at 774 .

167. It is important to note that in a recent decision, Justice Toley of the District of Nevada lield the United States liable for injuries suffered by workers exposed to radiation at nuclear testing sites. Implementing the Berkowitz test, discussed supra, Judge Toley found liability for failing to implement Chapter 0544 of the Atomic Energy Commission's Standard Operating Procedure by not establislimg an emergency plan and training in evacuation procedures. Judge Toley stressed that "if it is a cloice to be exercised within established objective safety standards, the discretionary function 
sufficient evidence exists to support such a claim but instead abjured in order "to avoid any judicial intervention that would require the courts to 'second-guess' the political, social, and economic judgments of an agency." 168

What the courts liave decided is that judicial review of how the government exploded atomic bombs is inappropriate. The reasons have little to do with judicial inability to evaluate the factual merits of the claims. Congress delegated authority using only the most vague terminology of protecting health and minimizing danger from nuclear explosion. The district court in Allen specifically found that, according to accepted standards of care, the decisions of test managers fell far sliort of their legal obligation to momitor the danger and to warn potentially affected meinbers of the public. ${ }^{169}$ Therefore, the district court in Allen resolved Judge Schwarzer's second factor-the ability of the judiciary to evaluate the challenged conduct-im plamtiff's' favor, and the appellate tribunal should liave approved this analysis.

It is significant that the Tenth Circuit's opimion relies neither on the proposition that the challenged decisions were made at the planning level, nor that the judiciary could not evaluate the challenged conduct. The Tenth Circuit's decision rests firmly on the third criteria: a judicial reluctance to interfere with or mipair the effective administration of national security policy. There is intuitive merit to judicial self-restraint in this context: Atomic testing was the exphicit manifestation of the ultimate policy question; to review what was done, and by whoin, would require assessments of causation and liabihty reaching to the very core of the national security establishment.

The flaw in the court of appeals' decision is that the judiciary's reluctance to review military discretion is without either definition or linitations. Is the critical factor the asserted connection between atomic testing and strategic deterrence policy, or is it the direct line of authority from the AEC officer at the site up to the President of the United States? As to the absence of limitations on the decision, is reckless conduct by a junior functionary completely immune simply because the judiciary does not believe that it is appropriate to review the conduct of atomic tests?

does not apply." The Allen decision was distinguished for the purported reason that those plaintiffs did not similarly allege a breach of mandated safety procedures. Roberts v. United States, $724 \mathrm{~F}$. Supp. 778, 791 (D. Nev. 1989). See also Prescott v. United States, 724 F. Supp. 792 (D. Nev. 1989).

168. Allen, 816 F.2d at 1424.

169. More recent evidence is startimg. Workers were told to recover instruments from tunnel and clean up rubble but were not furnished with respirators to protect their lungs. Indeed, when one shift of workers was hospitalized after exposure, the next shift was ushered in with no precautions. See Schneider, Nuclear Tests' Legacy of Anger: Workers See a Betrayal on Peril, N.Y. Times, Dec. 14,1989 , at 1 , col. 1 . 
It may be helpful to ask what conduct, if any, could have given rise to a hitigable claim. Judge Logan's opimion for the Tenth Circuit indicates that the plaintiffs would have had to prove that the test manager "failed to release information he was required to give out" or "failed to take a specific radiation measurement that had been decided upon." 170 This requirement signifies that the less defined the authority delegated to junior managers, the broader their discretion. Any decision made by those managers would be beyond review so long as the decision is in fact carried through. This extraordinarily broad delegation of authority is not justified by any accepted notion of administrative law, but is based fundainentally on the judiciary's unwillingness to intrude into military affairs. Like the Stanley hitigation, the plaintiffs' claims in Allen did not focus on the improper decisions of Pentagon planners; rather, their claims alleged that the atomic tests were conducted in a inanner that significantly ignored the health concerns of affected citizens and thereby violated their rights. No challenge was made to the policy decision to develop nuclear weapons nor to test prototypes. The claims were focused against the ground level managers at the test sites who decided where people would be stationed and what protective equipment would be distributed. Like the Supreme Court in Stanley, the Tenth Circuit in Allen decided against allowing sucl claims not because of deference to reasonable decisions reasonably executed, but rather because the national security implications of atomic testing placed those decisions beyond the reacli of judicial review.

The atomic testing litigation was, quite literally, a once-in-a-nation's-hifetime case. Never before has the government, acting in a noncombat situation, caused such widespread suffering. Hopefully, it never will again. It is liard to miagine that the federal courts again will be asked to hold in judginent military decisions of such consequence, so imbued witl national security considerations. It is unfortunate that the Supreme Court did not consider this matter of sufficient importance to grant certiorari. Furthermore, it is unfortunate that the undefined and limitless doctrine established in the atomic testing hitigation may be extended to controversies where the judiciary's reluctance to review "national security" cases is based on far less weighty considerations.

\section{BOYLE V. UNITED TECHNOLOGIES CORP. ${ }^{171}$}

Whereas the Atomic Testing Litigation and the Stanley decisions broadened governmental immumity for the inilitary's weapons testing, in

170. Allen, 816 F.2d at 1424 .

171. 108 S. Ct. 2510 (1988). 
Boyle the Suprene Court expanded this immunity to cover private weapons manufacturers. This radical leap taken by the Supreme Court bodes dire consequences for plaintiffs' efforts to hold the defense establishment legally accountable for the injuries that it causes.

\section{A. The Prima Facie Case and the Military Contractor Defense}

On April 27, 1983, Marine Lieutenant David A. Boyle's CH-53D helicopter crashed off the coast of Virginia Beach, Virginia, during a training exercise. Although Lieutenant Boyle survived the crash, he drowned in his helicopter because its escape hatch was defective. Boyle's parents sued United Technologies Corporation's Sikorsky Division, which built the helicopter for the United States, alleging that (1) Sikorsky had defectively repaired the "servo" in the helicopter's automatic flight control systen that nialfunctioned, thereby causing the crash, and (2) Sikorsky had defectively designed the copilot's emergency escape system so that it opened out imstead of in and was therefore meffective in a subinerged craft because of water pressure. The jury returned a verdict in plaintiff's favor for $\$ 725,000$.

The court of appeals reversed, holding that Sikorsky could not be held liable because its conduct was withm the "military contractor defense": 172
A military contractor can escape liability for a design defect if it can demonstrate tliat 1) the United States is immune from liability; 2) the United States approved reasonably precise specifications for the equip- ment; 3) the equipnent conformed to those specifications; and 4) the supplier warned the Umited States about the dangers in tlie use of the equipment that were known to the supplier but not to the United States. 173

The military contractor defense is a judicially-created doctrine that insulates weapons makers from hability to servicenen for injuries caused by defectively designed weapons. The defense is an extension of the Feres doctrine, ${ }^{174}$ which holds that the military may not be sued by servicemen for service-related injuries. Private corporations have successfully invoked Feres by proving that the government established specifications for the defective product, the product complied with those specifications in all material respects, and the government knew as much as or inore than the defendants about the hazards accompanying use of

172. Boyle, 792 F.2d 413, 414 (4th Cir. 1986), vacated, 487 U.S. 500 (1988). Decided as companion cases were Tozer v. LTV Corp., 792 F.2d 403 (4th Cir. 1986), cert. denied, 108 S. Ct. 2897 (1988), and Dowd v. Textron, Inc., 792 F.2d 409 (4th Cir. 1986), cert. denied, 108 S. Ct. 2897 (1988).

173. Boyle, 792 F.2d at 414.

174. Feres v. United States, 340 U.S. 135 (1940). See supra notes $28-34$ and accompanying text. 
the product. The doctrine's most oft-cited characterization comes from the Second Circuit's opinion in the Agent Orange litigation:

Subjecting military contractors to full tort hability would inject the judicial branch into political and military decisions that are beyond its constitutional authority and institutional coinpetence. The allocation of such decisions to other branches of government recognizes that military service, in peace as well as in war, is inherently inore dangerous than civilian life. Civilian judges and juries are not competent to weigh the cost of injuries caused by a product against the cost of avoidance in lost military efficiency. Such judgments involve the nation's geopolitical goals and choices among particular tactics, the need for particular technologies resulting therefrom, and the likely tactics, intentions, and risk-averseness of potential enemies. Moreover, military goods inay utilize advanced technology that has not been fully tested. Whereas judges and juries may deinand extensive safety testing for goods marketed in the civilian sector, such testing could impose costs and delays inconsistent with military imperatives. ${ }^{175}$

Underlying the military contractor defense is the difficulty of estabhishing which party is responsible for the defect. ${ }^{176}$ In the context of weapons procurement, where equipment choices necessarily implicate matters of national security policy, the failure to design for safety may not be a contractor's responsibility. ${ }^{177}$ Furthermore, to assign responsibility for a design defect necessarily would interject the fact finder into the decisionmaking realm of weapons design. The procurement of highperforinance weapons at the cuttimg edge of technology that are imtended for highly sophisticated military imssions demands a close working relationship between industry and government in weapons design and testing. The rationale for the military contractor defense, therefore, is the concern that judicial evaluation of the ultimate responsibility for a

175. In re "Agent Orange" Prod. Liab. Litig., 818 F.2d 187, 191 (2d Cir. 1987).

176. Even where an aspect of the design is unreasonably dangerous and where that aspect (defect) causes injury, a prima facie case under strict hability may be made only against the party who had a legal duty to act in such a way as to prevent the accident. The contractor will contend that the military reviewed and approved the final design and thereby intervened in the chain of causation such that the contractor was not responsible. This is especially problematic because most disputes involve factual allegations of a defect of omission - not claims that the accident was in fact caused by a design defect, but rather claims that the design was defective for failing to provide a means of protccting against such contingencies or to incorporate redundancy so that if one aspect of the equipment fails then it is not catastrophic. The finder of fact must determine, therefore, whether the military or private contractor bears responsibility for the absence of redundancy in the design of a weapon.

177. The military may have rejected an offer to build redundancy into the design. Perhaps redundant safety equipment would have been expensive or would have reduced soine aspect of the weapon's performance. Although it may be unreasonable to consider that the inihtary chooses broken teclinology, it is conccivable that the military might choose to eliminate redundancy for fiscal or performance reasons. 
weapon design decision might threaten a substantial intrusion into inilitary prerogative. 178

Although the courts have long recognized a contractor defense based on strict compliance with government contract specifications, ${ }^{179}$ two arguments justify opposition to attempts to broaden the inilitary contractor defense. First, while procureinent policy conteinplates a close working relationship between the military and nembers of the weapons industry, each party within this relationship has severable interests and obligations; in all material respects, the weapons acquisition system is supposed to reflect the operation of typical inarket forces. ${ }^{180}$ Second, the courts regularly and routinely consider issues similar to those raised in a serviceman's products hability suit. ${ }^{181}$ For a court of law to determine

178. In Tozer v. LTV Corp., 792 F.2d 403, $405-06$ (4th Cir. 1986), cert. denied, 108 S. Ct. 2897 (1988), the court opined:

The judicial branch contains no Department of Defense or Armed Services Committee or other ongoing fund of expertise on which its personnel may draw. Nor is it seemly that a democracy's most serious decisions, those providing for coinmon survival and defense, be made by its least accountable branch of government. . . .

Military contractors ordinarily work so closely with the military ... that it is nearly impossible to contend that the contractor defectively designed a piece of equipment without actively criticizing a military decision. Civilian scrutiny of such decisions is generally exerted through executive and legislative oversight on behalf of the public at large, not, as Id. here, through the judiciary at the behest of an individual serviceman.

179. See Yearsley v. W.A. Ross Constr. Co., 309 U.S. 18, 21 (1940); Meyers v. United States, 323 F.2d 580, 583 (9th Cir. 1963). The contract specification defense does not, however, bar an action alleging the weapon's design "represented ... something less than the uppermost level of the art." O'Keefe v. Boeing Co., 335 F. Supp. 1104, 1124 (S.D.N.Y. 1971). See generally Challoner v. Day \& Zimmerman Inc., 512 F.2d 77 (5th Cir. 1975) (a nonseller, here a manufacturer who assembled parts bought by the government, can be held strictly liable, despite the fact the design was in the government's exclusive control), vacated, 423 U.S. 3 (1975) (reinanded for inisapplication of choice of law rules).

180. In a 1985 hearing before the Senate Judiciary Committee, a Defense Department official stated:

In the commercial world, risks of third party liability are covered by insurance or are assumed by the manufacturer. In defense contracting, we believe this should also be the case.... We prefer to contract in an environinent similar to the commercial marketplace where coinpanies must take all the steps that would be required by a prudent businessinan in order to ensure the safety of the company's product.

Indemnification of Government Contractors: Hearings Before the Senate Comm. on the Judiciary, 99th Cong., 1st Sess. 30 (1985) (statement of Mary Ann Gilleece, Deputy Under-Secretary of Defense for Acquisition Management). See generally The Competition in Contracting Act, 31 U.S.C. $\S 3553$ (Supp. V 1987); Efforts by Federal Agencies to Circumvent the Competition in Contracting Act: Hearing Before a Subcomm. of the House Comm. on Gov't Ops., 99th Cong., 2d Sess. (1986).

181. A significant body of law has distinguished contractor compliance with advertised design specifications from contractor design of a weapon in a negotiated contract containing only vague performance specifications. Some of the leading decisions focusing on this distinction include Penguin Indus. v. United States, 530 F.2d 934 (Ct. Cl. 1976); NOA Airscrew Howden, Inc. v. United States Dep't of the Army, 622 F. Supp. 984 (E.D. Mich. 1985); Washington Mechanical Contractors v. United States Dep't of the Navy, 612 F. Supp. 1243 (N.D. Cal. 1984); Self-Powered Lighting, Ltd. v. United States, 492 F. Supp. 1267 (S.D.N.Y. 1980); Appeal of Aerodex, Inc., 1962 B.C.A. (CCH) If 17,819 (1962). 
who is responsible for a defective product does not require inquiry into military policy and in fact is a determination regularly made. ${ }^{182}$

In cases involving the military contractor defense, the issue has focused on the evidence necessary to determine whether the United States approved reasonably precise specifications for the equipment. Tort plaintiffs have sought to put the burden of proof on the contractor to show coniphance with the military's design specifications; defendants sought to impose the burden of proof on the plaintiff to show that the contractor deviated from the contract specifications. In a series of decisions beginning with McKay v. Rockwell International Corp., ${ }^{183}$ the appellate courts have debated whether the military contractor defense permits a manufacturer to invoke the defense in situations where the manufacturer selects the defective design and the military merely approves it. The Ninth Circuit in McKay and the Fifth Circuit in Bynum v. FMC Corp. ${ }^{184}$ refused to impose a burden on the contractor to show that it lacked discretion in the design of the equipment. According to the Fifth Circuit's opinion:

[A] requirement of compulsion of this sort would discourage military contractors from bidding on government projects or, alternatively, give the contractors incentive to pressure the military to purchase safer equipinent. Either result would be contrary to sound public policy which ... requires that contractors be encouraged to enter into contracts with the government for the production of inilitary hardware .... [T] he contractor, like the judiciary, should not be thrust into the position of second-guessimg military decisions. ${ }^{185}$

This position coufers a virtual immunity froin hability on any weapons inanufacturer that is forfeited only by failing to warn of known hazards; it essentially extends sovereign immunity to private coinpanies. By contrast, the Eleventh Circuit in Shaw v. Grumman Aerospace Corp. ${ }^{186}$ recognized a judicial role in determining whether the military, in fact, had

182. See Northrop Corp. v. McDonnell Douglas Corp., 705 F.2d 1030, 1047 (9th Cir. 1983), cert. denied, 464 U.S. 849 (1983):

Northrop does not challenge the wisdom or legality of any governmental act or decision. Instead, it seeks to restrain and recover damages from McDonnell for the latter's allegedly improper tactics in marketing F-18's.... The mere fact that the challenged conduct occurred in a regulated industry does not alone alter its private commercial character. The issues presented for trial are not political questions-they are legal issues, involving private commercial activity which the judiciary is uniquely equipped to resolve.

Id.

183. 704 F.2d 444 (9th Cir. 1982), cert. denied, 464 U.S. 246 (1984). For citations to decisions rendered between McKay and Boyle, see supra note 47.

184. 770 F.2d 556, 577 (5th Cir. 1985).

185. Id. at $574-75$.

186. 778 F.2d 736 (11th Cir. 1985), cert. denied, 108 S. Ct. 2896 (1988). According to Shaw, the manufacturer must prove the negative proposition that the design in question does not represent its own judgment by showing either that (1) it did not participate in the design of the defective product, or (2) it warned the military of the risks of the design. Only if the military commanded the decision to employ the allegedly defective design would judicial deference be warranted. Id. at 746-47. 
decided that the risk of injury to servicemen from a particular design defect is a risk that the military willingly took. The Supreme Court granted certiorari in Boyle to resolve this conflict among the circuit courts.

\section{B. The Supreme Court's Boyle Decision}

Justice Scalia's opinion for the inajority begins with the recognition that in most fields, the Court has refused to find federal preemption of state law im the absence of a clear statutory prescription or a direct conflict between federal and state laws. But in a few areas, those involving "uniquely federal interests" that are so committed by the Constitution and laws of the Umited States to federal control, state law is preempted and replaced by so-called federal common law. The dispute in the present case borders upon two areas involving "uniquely federal interests" that are governed exclusively by federal law: (1) obligations to and rights of the United States under its contracts, and (2) the scope of hability of federal officials for actions taken in the course of their duties. Weapons procurement by the United States is an area involving uniquely federal interests because the imposition of hability on government contractors would directly affect the terms of governinent contracts: "[E]ither the contractor will decline to manufacture the design specified by the Government, or it will raise its price. Either way, the interests of the United States will be directly affected." 187

In order for this uniquely federal interest to displace state law, there must be a significant conflict between state law and federal policy. Here the state law duty of care asserted as the basis of the contractor's liability (specifically, the duty to equip helicopters with the sort of escape-hatch mecliamism petitioner clainis was necessary) is directly contrary to the duty iniposed by the federal government (the duty to manufacture and dehiver helicopters with the sort of escape-hatch mechanisin described in the contract specifications). Even here, it would be unreasonable to say that there always is a "significant conflict" between the state law and a federal pohicy or interest. "If, for example," Justice Scalia suggested, "a federal procurement officer orders, by model number, a quantity of stock lielicopters that liappen to be equipped with escape hatclies opening outward, it is inipossible to say that the Government lias a significant interest in tliat particular feature."188 Thus there must be a limiting principle to identify situations in which a "significant conflict" exists between federal policy and state tort law.

187. Boyle v. United Technologies Corp., 108 S. Ct. 2510, 2515 (1988).

188. Id. at 2516. 
Justice Scalia rejected the court of appeals' use of the Feres doctrine as that limiting principle. The Feres rationale that the contractor's tort liability would increase the product's cost and be passed on to the government, thereby deflecting the purpose of the government's immunity for military accidents, produces results that Justice Scalia found are in soine respects too broad and in other respects too narrow. They are too broad because if the contractor defense prohibits suit against the manufacturer whenever Feres would prevent suit against the government, then even injuries caused by equipinent purchased from stock would be covered; the result is too narrow because Feres only covers service-related injuries, not a civilian's injuries caused by the military. Thus, a civilian's suit against the inanufacturer of fighter planes-e.g., a state tort claim for liarm from excessively high levels of noise produced by jet engineswould not be barred by a military contractor defense based on Feres. Yet, the design of the jet engines the government orders for its fighter planes cannot be regulated by state tort law, no more in suits by civilians than in suits by members of the armed services.

Justice Scalia instead found a statutory provision defining the outlines of "significant conflict" between federal interests and state law in the context of government procurement: the FTCA's discretionary function exception. The selection of the appropriate design for military equipinent is certainly a discretionary function within the meaning of this provision. Second-guessing these selections througli state tort suits against contractors would produce the saine effect the FTCA exemption seeks to avoid. The financial burden of judginents against the contractors ultinnately would be passed through to the United States itself in higher prices to insure the inanufacturer against contingent liability for the government-ordered designs. According to Justice Scalia, "it inakes hittle sense to insulate the Government against financial liability for the judgment that a particular feature of military equipinent is necessary when the Government produces the equipinent itself, but not when it contracts for production."189 Thus, the Supreme Court adopted $M c$ Kay's three criteria of displacement based not on Feres, but ratlier on the discretionary function exception of the FTCA: (1) the United States approved reasonably precise specifications; (2) the equipnient conforined to tliose specifications; and (3) the supplier warned the United States about equipnient dangers known to the supplier but not United States. ${ }^{190}$

The Court rejected the Eleventh Circuit's alternative formulation of the contractor defense- suit is precluded only if (1) the contractor's par-

189. Id. at 2518.

190. Id. 
ticipation in the design of the defective equipment was minimal or less, or (2) the contractor warned the government of known risks and the government nevertheless clearly authorized the contractor to proceed-since that formulation failed to protect the federal interest einbodied in the "discretionary function" exemption:

The design ultimately selected may well reffect a significant policy judgment by Government officials whether or not the contractor rather than those officials developed the design. In addition, it does not seem to us sound policy to penalize, and thus deter, active contractor participation in the design process, placing the contractor at risk unless it identifies all design defects. ${ }^{191}$

Not the need to preserve military discipline but the need to preserve contractor participation in the weapons design process justified the Supreme Court's holding.

Justice Brennan, dissenting with Justices Marshall and Blackmun, accused the majority of having "unabashedly stepped into the breach to legislate a rule denying Lt. Boyle's family the coinpensation that state law assures them. This time the injustice is of this Court's own making."192 Justice Brennan noted that Congress has reinained conspicuously silent in the face of a sustained campaign by governinent contractors to create a statutory defense, ${ }^{193}$ and yet the decision to displace state law by enacting a federal rule in an area of national concern generally is inade by the people through their elected representatives in Congress.

Furthermore, the Court's government contractor defense is breathtakingly sweeping:

It applies not only to military equipment like the CH-53D helicopter, but (so far as I can tell) to any made-to-order gadget that the Federal Government might purchase after previewing plans-from NASA's Challenger space shuttle to the Postal Service's old mail cars. The contractor may imvoke the defense in suits brought not only by military personnel like Lt. Boyle, or Government employees, but by anyone imjured by a Government contractor's negligent design, including, for example, the children who might have died had respondent's helicopter crashed on the beach. ${ }^{194}$

Justice Brennan argued that even granting the inajority's factual premise that suits agamst contractors will preclude the governinent from purchasing the desired product at the price it wants, the inajority cited no authority for the proposition that hability costs imposed on govern-

191. Id.

192. Id. at 2520.

193. Id. Justice Brennan cited six House Reports concerning civil liability of government contractors to show continued congressional opposition to a special defense for those contractors.

194. Id. 
ment contractors, but passed on to the government, burden the government in a way that justifies extension of its immunity to cover private contractors. In other contexts, the Court has held as legally irrelevant the fact that the government might have to pay higher prices for the products it orders if the seller might be exposed to civil hability.

Justice Brennan characterized the Court's analysis as premised on the proposition that any tort liability absorbed indirectly by the government so burdens government functions as to compel the judicial creation of immuinity, even though Congress has refused to legislate this requirement. But that proposition is by no means uncontroversial. Perhaps tort hability is an inefficient ineans of ensuring safe product designs, but whatever the merits of the policy the Court may wish to impleinent, such pohicymaking is a subject more appropriate for congressional action than for the creative power of the judiciary. As Justice Brennan observed,

The tort system is premised on the assumption that the imposition of liability encourages actors to prevent any injury whose expected cost exceeds the cost of prevention. If the system is working as it should, Government contractors will design equipment to avoid certain injuries (like the deaths of soldiers or Government employees), which would be certain to burden the government. The Court tlierefore has no basis for its assumption that tort hability will result in a net burden on the Government (let alone a clearly excessive net burden) rather than a net gain.

Were I a legislator, I would probably vote against any law absolving multibillion dollar private enterprises from answering for their tragic mistakes, at least if that law were justified by no more than the unsupported speculation that their hability might ultimiately burden the United States Treasury. Some of iny colleagues here would evidently vote otlierwise, but that should not matter liere. We are judges not legislators, and the vote is not ours to cast. ${ }^{195}$

Justice Stevens also dissented in Boyle:

When judges are asked to embark on a lawmaking venture, I beheve they sliould carefully consider whether they, or a legislative body, are better equipped to perform the task at hand ....

When the novel question of policy involves a balancing of the conflicting interests in the efficient operation of a massive governmental program and the protection of the rights of the individual, I feel very deeply that we should defer to the expertise of the Congress. ${ }^{196}$

According to the four dissenting Justices, it was up to Congress to protect the weapons procurement system from price inflation that could result from imposition of liability. The five-to-four fracture of the Court

195. Id. at 2528 (Brennan, J., dissenting).

196. Id. 
ironically inverted the expected alignment in that Justices Scalia, Rehnquist, O'Connor, White, and Kennedy were accused by the so-called "liberal" Justices of liaving usurped authority froin the political branches ratlier tlian neutrally enforcing the law as written.

\section{The Purpose of Deference to Military Discretion-Part III}

The Supreine Court could have affirmed Boyle on the basis of the military contractor defense because the Feres immunity inay be extended to private contractors when the contractor is not negligent in failing to inform the government of known defects. Justice Scalia's extraordinary opinion explicitly rejects this rationale in favor of an extension of the discretionary function exception. Obviously, a private corporation is not protected by the doctrime of sovereign immunity that underlies the exceptions to FTCA liability. Justice Scalia asserts, however, that since the same considerations apply, it is not "sound policy to penalize, and thus deter, active contractor participation in the design process." 197 Thus by judicial extension, the same protection afforded to the governnent official who exercises discretion in purchasing weaponry now covers the private contractor supplying tliose weapons. The transaction itself is a discretionary function into which the courts should not intrude; the nilitary command considerations underlying Feres are tlius inapposite.

The difference in the two approaclies-application of the inilitary contractor defense or Justice Scalia's extension of the discretionary function exception-is seemingly this: Under the military contractor defense, servicemen (not civilians) were barred from suing contractors for defective equipment regardless of the nature of the equipment, whereas under the Court's extension of discretionary function, everyone (servicemen as well as civilians) is barred from suing contractors for injuries caused by defective weapons that are sufficiently sophisticated that the governnient cannot purchase them off the shelf. The concern is not the nuilitary chain of cominand relationship between prospective hitigants which might be threatened by a tort claim barred by the Feres doctrine. Apparently, it does not inatter whether the plaintiff is a servicemen or a civilian. The only grounds for denying this defense is that the injuries were caused by equipinent purchased from stock. The concern driving the Court is the national security implications of judicial inquiry into the weapons procurement process.

The first objection to the Court's extension of the discretionary function exception concerns the respective authority of the judiciary and the legislature. As tle dissenting opinions ardently argue, the soundness of a

197. Id. at 2517. 
policy that may increase the government's cost for weapons is a matter best for Congress to decide. The absence of positive law must mean that Congress, having balanced all the competing factors, decided not to intervene in this matter. By what authority does the Court determine that the imposition of higher costs on defense contractors contravenes uniquely federal imterests?

A second and perhaps more telling objection is that the Supreme Court has encroached on congressional terrain selectively and intentionally: reading Boyle together with Stanley reveals a clear image of this Court's viewpoint. The questions left open in Stanley are answered im Boyle: Must it be established that a military decision was directly connected to a policy position taken by legitimate congressional or Executive authority? Are there limits to the immunity such that unjustifiable conduct taken at the "operational level" may be actionable even if policy planning is immune? Are there criteria that distinguish matters of national security concern from the caprice of mid-level Pentagon managers? After Boyle, the answer to each of these questions apparently is "no" whenever the weapon involves complex technology-i.e., it is not "off-the-shelf"- -such that the procurement decision involves selection of a unique or sophisticated design. Where the technical sophistication of the weapon requires that the military make a choice, then judicial review of that procurenient choice would interfere with the military sphere. Thus, the Boyle decision not only encroaches on a policy matter best left for Congress and proinulgates a doctrine that is essentially boundless, but Justice Scalia's Boyle opinion also is a profound stateinent of national security policy. At bottoin, it rests on the assumption that the procurement of sophisticated weaponry is itself the discretionary execution of national security policy and thus is necessarily outside the realm of judicial review and hence of legal accountability.

Justice Scalia deserves credit for making explicit the underlying implications of the military contractor defense. By explaining that contractor immunity is derived froin the discretionary function exception, the Court has vested weapons makers with the historically ultimate justification for sovereignty: In return for the protection provided against external threat, the public cedes unchallenged fealty. Legal review of procurement choices is therefore offensive because military security demands ever more technologically sophisticated destructive capability; to review the weapons selection process would imtrude upon the military's efforts to deter enemies because contractor accountability would make the necessary weapons more expensive. The result is that the concern for national security asserted by those who claim to protect the nation, whether properly authorized public officials or private menibers of the 
defense establishment, insulates entire sectors of the procurement process from judicial review. According to five Supreme Court Justices, legal process is inappropriate: Simce the production of sophisticated weaponry is the essence of national security, those who produce such weaponryindeed the entire process by which such weaponry is produced-are entitled to tort immunity. Whatever weapons are niade and whatever harm is caused as a result, the courts will not afford injured plaintiffs legal redress.

Iniportant values are at stake here. Lieutenant Boyle died within three miles of the United States coast, not at the hands of enenies but because of an alleged design defect $\mathrm{m}$ his hehicopter. The "uniquely federal interests" that displace tort hability for his death have remarkably little to do with deterring threats whether from terrorists or Soviet ICBM's. Lieutenant Boyle's parents challenged neither the pohicy to test hehicopters at sea nor tlie military command ordering Lieutenant Boyle to fly that defective hehicopter. Like Master Sergeant Stanley and the victims of atomic testing, the plainti here challenged the nianner by which a military weapons testing prograin was executed and sought to hold accountable those who should have prevented the unnecessary loss. And like those claims, the claims of Lieutenant Boyle's parents were rendered nonjusticiable because of the judiciary's unwillingness to review military affairs.

The Supreme Court's refusal to adjudicate the tort claims of Lieutenant Boyle's parents denionstrates an unmistakable appreciation of the military-industrial coniplex; the Court assumes without hesitation that the weapons industry is intimately involved with the military's performance of strategic policy responsibilities. The Court's reasoning rests on the premise that because weapons niakers help guide inilitary policy, their discretionary decisions are cloaked with sovereign inımunity. Thus, the selection of design specifications by United Technologies is nonjusticiable in the same way that a Defense Departnent decision on nilitary policy may not be judicially reviewed. In either case, the Court has deened that the matter for review is outside the judiciary's powers.

The Suprenie Court's granting of sovereign immunity to United Technologies and its conpetitors is an unjustified (and unjust) constriction of article III review of military procurenent decisions. The weapons makers supplying the United States' arsenal participate in an international inarketplace generating wealth beyond the dreams of avarice. Strategic deterrence policy requires that every new weapons systen be met by a more sophisticated and intimidating system; every first strike capability must be counterbalanced by a superior second strike capability. The deniand is insatiable because the developnent of any capability 
by one side precipitates the development of a greater capability by the other. Suppliers to this dialectic of threat and deployment are now, according to the Supreme Court, legally unaccountable for their tortious designs. The soldiers are, after all, expendable-it is the unique symbiotic relationship between the military and the weapons makers that must be preserved. The masters of war, unaccountable to the prevailing standards of conduct, are the warrior class with privileges all their own.

\section{CONCLUSION}

There is a difference between deference and abdication. Judicial deference is a reasonable accommodation of the judiciary's limited role as one of three branches of the federal government. For a court to be deferential imphies that some other branch of government has greater expertise over the matters in question, and the costs of constant judicial oversight far outweigh the benefits. Deference is thus a cornerstone of administrative law grounded in the judiciary's essential conservatism about the extent of its own expertise. In the context of weapons testing and national security, it is hard to disagree that the judiciary should be deferential about the need for weaponry, the best method of testing and developing such weaponry, or the allocation of risks associated with such weaponry.

Even in this context, judicial deference should be based on a showing that (1) authority for the activity causing the injury was delegated from either Congress or senior Executive officials; (2) the agent responsible for the injnry acted within the scope of that authority; and (3) the decision to place persons at risk of harm was reasonable in hight of the evidence that a prudent administrator would consider under the circumstances. Deference is not carte blanche. It is not so much an immunity afforded to government agents as it is a concept built of the respect that the judiciary nust have for the legitimate exercise of authority by the coordinate branches of the government. 198 A decision that reflects the weight of the evidence, undertaken by properly authorized officials within the scope of their delegated authority, should not be overturned

198. Consider the following conclusions drawn by Professors Shapiro and Levy in Heightened Scrutiny of the Fourth Branch: Separation of Powers and the Requirement of Adequate Reasons for Agency Decisions, 1987 Duke L.J. 387, in regard to the role of judicial review:

The recent emergence of rationalism, which focuses on substantive review of the rationality of agency decisions, is a promising approach to judicial review-if understood as a requirement of separation of powers. . . By imposing heightened scrutiny under separation of powers principles, rationalism establishes judicial review of agency action as an effective check on agency action.

Id. at 440 . 
simply because a court, in hindsight, would have made a different decision.

Abdication is another matter altogether. Abdication is a refusal to hear a type of legal claim because the very process of hearing the clain would constitute a judicial intrusion on the military sphere. Abdication ignores the role of checks and balances in our system and holds that there is an institution, already the most powerful in our society, that is outside the sphere of judicial review. The cases discussed above demonstrate that the judiciary has abdicated its role in our system. As evidence of this abdication, it would be useful to ask what activities the military could pursue that would, in hight of the three decisions discussed, give rise to tort hability? That is, what weapons testmg activity might conceivably be sufficiently egregious to cause harm, sufficiently "operational" to be non-discretionary, and sufficiently outside activities "incident to service" to create civil hability? What loss of constitutional rights would be reviewable in the face of the military establishment's claim that review would jeopardize national security? The answer to these questions shows that it is difficult even to hypothesize conduct that conceivably would be accountable in tort.

Consider whether the United States could be liable to anyone in a United States court for having accidently lost a hydrogen bomb in 1965 off the Japanese Coast. Here again is a pattern of an accident during a training mission, followed by years of silence. Apparently no one has been hurt and the chances of detonation are extremely remote. ${ }^{199}$ However, it is clear that if someone had been hurt, either due to detonation or because the bomb landed on something, under the precedent of the three opmions discussed there would be no hability for injuries or for failing to admit the accident for twenty-four years. The decision to fly bombers equipped with hydrogen bombs in the western Pacific was a policy decision made at sufficiently high levels to be discretionary. If the A-4 aircraft that carried the weapon crashed due to a defect in its design, Boyle certainly would insulate the private contractor from liability. Of course, this result would hold true if the island where the bomb fell was Oahu rather than Okinawa.

Further, consider the hability for environinental injuries caused by the nuclear weapons facilities throughout the United States. The Department of Energy has closed virtually all its weapons production plants because of safety problems. Most facilities have contaminated groundwater with radioactive or hazardous substances. The Savannah River facility has been shut down because irradiation and stress cracks have

199. Sanger, A Missing H-Bomb Ruffles Japanese, N.Y. Times, May 11, 1989, at A15, col. 1. 
made pipes and tanks vulnerable to leakage. At the Hanford Reservation, workers have been contaminated with plutonium. At Rocky Flats, toxic emissions have entered the groundwater. Perhaps most noteworthy is that the Department of Energy's facility at Fernald, Ohio, has released hundreds of tons of potentially dangerous uranium and unknown quantities of hazardous chemicals into the environment. ${ }^{200}$ Although the federal government has agreed to make payments of $\$ 275,000$ in fines to the state for violating Ohio standards for clean air by illegally releasing radioactive radon and uranium, the Department of Energy appealed, on the grounds of sovereign immunity, the imposition of a $\$ 250,000$ penalty for violations of the Federal Clean Water Act. ${ }^{201}$ Under the Price-Anderson Act (as amended), victims of accidents at nuclear plants may receive up to $\$ 7$ billion in daniages fron the federal government. ${ }^{202}$ But under the precedent of Allen v. United States, it is not clear that an action could proceed without being defeated by claims that the operation of the plant was a "discretionary function."

The clear answer to many of the issues raised herein is for Congress to enact legislation that specifically authorizes the judiciary to hear tort claims arising from weapons testing activities. Whether such legislation is politically possible is beyond hypothesis. But it is noteworthy that Congress, even if it passed such a statute, may lack authority to require justiciability of tort claims if the Supreme Court beheves that military security is involved. Consider in this context Justice Scahia's dissent in Webster v. Doe. ${ }^{203}$ An employee of the Central Intelligence Agency, allegedly fired because of his homosexuality, asserted statutory and constitutional claims. The majority of the Court per Chief Justice Rehnquist ruled that only claims based on deprivation of constitutional rights could proceed. Justice Scalia's dissent argued that judicial review, even of constitutional claims, was inappropriate. He placed "national security" in the body of jurisprudence that has inarked out "certain issues and certain areas that were beyond the range of judicial review."204 According to Scalia, jurisprudence principles ranging from the "political question"

200. Glenn, The Mini-Hiroshima Near Cincinnati, N.Y. Times, Jan. 24, 1989, at A21, col. 2. Over thirty thousand children have been exposed to high levels of radioactive iodine near the Hanford facility in Washington State. In the past two years, the Department of Energy has closed nine weapons research and production facilities because of operational and safety problems. All but one of them have groundwater highly contaminated with radioactive or hazardous substances. Six have soil contamination, including offsite locations.

201. Wald, U.S. Will Pay Ohio to Settle Charge at Nuclear Plant, N.Y. Times, Apr. 11, 1989, at A1, col. 1.

202. Kellman, The Scandal of Home-Grown Nuclear Blackmail, L.A. Herald Examiner, Apr. 24,1988 , at F3, col 2.

203. 108 S. Ct. 2047, 2055 (1988).

204. Id. at 2056. 
doctrine, to sovereign immunity, to official immunity, to prudential linitations upon the courts' powers, call into question

whether Congress could constitutionally permit the courts to review such decisions if it wanted to. We have acknowledged that the courts cannot intervene when there is a "textually demonstrable constitutional commitment of the issue to a coordmate political department." We have recognized "the insistence (evidence from the number of Clauses devoted to the subject) with which the Constitution confers authority over the Army, Navy, and militia upon the political branches."205

At least one Supreme Court Justice, the author of both the Stanley and the Boyle decisions, thus has called into question whether congressional authorization of tort hitigation would be sufficient to overcome the Court's unwillingness, jurisprudentially, to review military affairs.

What is the underlying basis for the Court's fear that it will interfere with the military? Of course, the United States has real security needs, and the military's response to those needs should not be inatters for judicial review. But those security needs are not always at stake. There have to be limits to this concept of judicial deference. If there are no limits, then the threat of an external enemy, ever vigilant to destroy us if our military is at all constrained, will be used to justify the loss of the very freedom and security that we seek. If there are no criteria by which courts may determine whether a given decision is indeed the essence of national security policy, then the primary force of accountability-judicial review-will be barred at the Pentagon's gate.

Underlying this call for criteria is the behef that the age of nuclear deterrence poses special problems for the application of law to the military establishment. America has spent much of the twentieth century defending liberty, and only a fool would claim that victory may be declared and our guard let down. Yet America is not at war. While the many threats that the nation must face coinpel readiness, no state of war exists. Recent revolutionary changes in the Eastern Bloc nations present this country witli a unique opportunity to reflect on the Cold War and the policies it spawned. Despite these imporved prospects and the fearsome military capabilities of the Soviet Union and of the United States, weapons testing escalates.

In an age of nuclear weapons, "mutual assured destruction" has become tlie ultimate justification for the sovereign's immunity: If military autliority is interfered with by judicial review, then the chance of thermonuclear holocaust may increase and we may all be destroyed. Such was the justification of medieval knights who literally obeyed a different code

205. Id. at 2061. 
than that obeyed by civilian subjects. But medieval knights could never point to any external threat-any dragon in the woods-quite so terrifying as Soviet ICBMs. It must be remember however that these modern protectors, the armored and immune United States military, have caused more death and disease than any Soviet weapon. Now, judicial abdication to the purported needs of the warrior class renders us all the bearers of the unknown and unknowable consequences of weapons testing.

What we do know is that American citizens have been drugged, radiated, and neghigently equipped-and no one is legally accountable. 